Departamento de Anatomia Descritiva dos Animais Domesticos Prof. Dr. M. Barros Erhart

Departamento de Zootecnia Geral, Genetica Animal e Bromatologia Prof. Milton de Souza Piza

\title{
CONTRIBUIÇÃO PARA O ESTUDO DA LOCALIZAÇÃO DO CENTRO DE GRAVIDADE NO CORPO DOS ANIMAIS DOMESTICOS E DOS FATORES QUE PRODUZEM SEU DESLOCAMENTO TEMPORARIO OU PERMANENTE
}

POR

\author{
Armando Chieffi e Lafayette Homem de Mello \\ Assistentes
}

Com 40 figuras no texto e 2 estampas

I

DESLOCAMENTO DO CENTRO DE GRAVIDADE

NAS ATITUDES, NOS MOVIMENTOS SOBRE O LUGAR, NOS

ANDAMENTOS E NOS SALTOS DO CAVALO (*)

Este trabalho, que faz parte dos estudos que estão sendo feitos sobre a localização do centro de gravidade no corpo dos animais domesticos e dos fatores que produzem seu deslocamento temporario ou permanente, propõe-se a estudar o deslocamento do centro de gravidade e os diversos modos de locomoção do cavalo. Esta parte é destacada, à vista da discordancia notada entre os diferentes autores e mesmo entre êstes e nossas observações pessoais, principalmente no que diz respeito ao salto.

Começando por um ligeiro historico dos estudos que foram feitos nêsse sentido, seguem-se os rudimentos de estatica em que se baseia o equilibrio dos quadrúpedes e sua aplicação nas atitudes e nos movimentos. A seguir, serão dadas breves noções sobre a fisiologia da locomoção e da tração e sôbre cada andamento em particular, terminando pelo estudo do mecanismo do salto.

Ao presente trabalho seguir-se-ão outros sôbre os andamentos do cavalo Mangalarga, sôbre a localização do centro de gravidade nos animais domesticos e suas variações de conformidade com a idade e o sexo, de onde poderão ser tiradas interessantes conclusões quanto à especialização zootecnica, crescimento, etc., das diversas especies e raças.

Nossas observações para o estudo da locomoção foram feitas em 50 animais da Sociedade Hípica Paulista e da Coudelaria Paulista, que foram filmados em camara lenta, com 64 imagens por segundo.

(*) Comunicado à Soc. Paulista de Med. Vet. em 9-XI-1938. Nota prévia publicada em "O Veterinario". Orgão do Centro Academico IX de Julho da Fac. Med. Vet. de S. Paulo. Ano II, n. 3 Julho de 1938. 
Procurámos obter o maior numero possivel de saltos, afim de elucidar as divergencias notadas entre os diversos autores e nosso ponto de vista particular. Foram todos observados em animais montados, quer em competições hípicas (êstes em maior numero), quer executados unicamente para fins de demonstração, não nos sendo possivel observá-los em animais em liberdade, nos quais os movimentos seriam mais naturais, pois é inegavel que certas modificações do salto são provocadas pelo cavaleiro. Tanto assim é que, um dos cavalos, depois de ter feito seis saltos de demonstração, de acôrdo com nossas previsões, contrariou a sucessão dos apoios que julgamos normal, quando montado por outro cavaleiro menos experimentado.

Os films utilizados para o nosso estudo ficaram fazendo parte do Arquivo do Departamento de Zootecnia Especial da Faculdade de Medicina Veterinaria da Universidade de São Paulo.

Cabe-nos agradecer aos Diretores da Faculdade e, em particular, aos Professores Max de Barros Erhart e Milton de Souza Piza, Dr. Paulo de Lima Corrêa, Diretor do Departamento de Industria Animal, Cap. Béla Wodianer, Diretor da Coudelaria Paulista, e Sr. Elias Alves Lima, Diretor da Sociedade Hípica Paulista, o valioso auxílio que nos prestaram. Agradecemos ainda ao Dr. Djalma Lepage, a quem devemos os desenhos que ilustram este trabalho.

\section{HISTORICO}

Desde muito, os autores se vêm preocupando com a determinação do centro de gravidade nas diferentes atitudes e movimentos dos animais.

Borelli (De motu animalium) acreditava que o centro de gravidade, nos quadrúpedes, estivesse colocado na metade da altura do tronco, sôbre a perpendicular levantada da intersecção das diagonais da báse de sustentação. Nestas condições, o pêso do corpo repartirse-ia igualmente pelos quatro membros. Entretanto, como observou LECOQ, a cabeça e o pescoço constituem u'a massa pesada, que sobrecarrega os membros anteriores, o que o levou a supôr que o centro de gravidade estivesse colocado mais abaixo e mais para a frente do que o ponto estabelecido por Borel.LI. Concluiu ainda, em virtude da simetría bilateral do tronco, que o referido ponto devia estar situado no plano vertical mediano.

Colin, em seu Tratádo de Fisiologia comparada, foi mais preciso na determinação do centro de gravidade, estabelecendo que, nos cavalos, êle estaria sobre o plano precedentemente citado, «na intersecção de uma vertical tangente ao apêndice xifoide do esterno com o plano horizontal que divide o terço inferior dos dois terços superiores da 
profundidade toracica, isto é, na altura do terço inferior da oitava costela e pouco atrás da base do coração» (Fig. 1). . Êste A., além de deslocar muito posteriormente a base do coração, provavelmente se refira à margem caudal do orgão. ZIMMERL considera como limite posterior extremo a sexta costela.

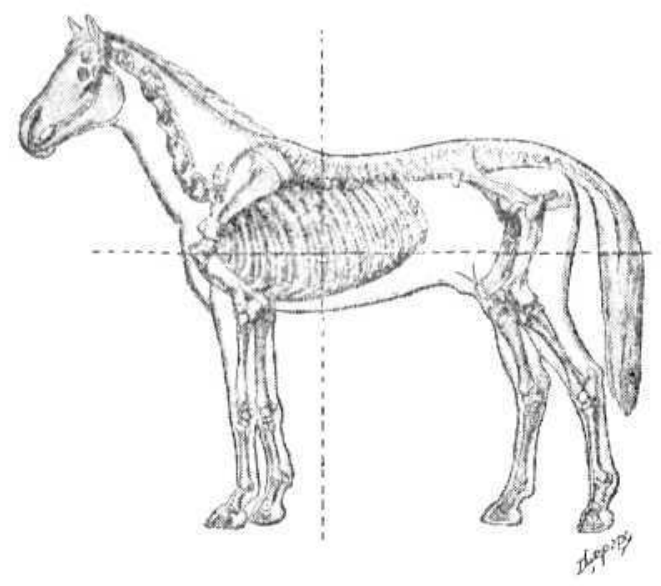

Fig. 1 - Localização do centro de gravidade, segundo Colin (W. Ellenberoer - H. BAum)

A posição do centro de gravidade e a distribuição do pêso do corpo sôbre os membros variam nos diversos individuos, segundo sua conformação, e tambem no mesmo animal, conforme suas atitudes e andamentos. As menores mudanças de posição do pescoço e da cabeça, as proprias oscilações do diafrágma, durante os movimentos respiratorios, bastam para deslocá-lo, como demonstraram as experiencias de MORRIS E BAUCHER.

\section{NOÇÕES DE ESTÁTICA}

GRAVIDADE, CENTRO DE GRAVIDADE E LINHA DE GRAVITAÇÃO

A simples observação nos leva a verificar a existencia de uma força que, atuando sobre todos os corpos, solicita-os na direção do centro da terra. Esta força recebe o nome de gravidade.

Se um corpo fôr dividido em diversas partes, cada uma delas estará igualmente subordinada à ação da gravidade. Daí se conclue que esta se exerce sobre cada uma das particulas componentes do corpo, constituindo, em seu conjunto, um sistema de forças paralelas, cuja resultante é medida pela pressão que o corpo exerce sôbre o obstáculo que impede sua quéda. O ponto de aplicação da resultante do sistema recebe o nome de centro de gravidade. E' facil sua determinação nos 
sólidos geometricos. Já o mesmo não se verifica na determinação do centro de gravidade dos seres vivos, porquanto os movimentos das partes articuladas, o deslocamento das visceras, sua modificação em pêso e volume, etc., fazem com que o centro de gravidade não seja fixo. Para determinação de suas variações extremas, torna-se necessario o conhecimento da linha de gravitação e da báse de sustentação ou de apoio. A linha de gravitação é a vertical baixada do centro de gravidade. A báse da sustentação é representada pelo espaço limitado pelas linhas que unem os pontos de apoio dos membros. Nos quadrúpedes, ela pode ser um quadrilatero ou um triangulo, conforme a estação seja forçada ou livre. Na primeira, os quatro membros tomando parte no apoio, a báse de sustentação é um quadrilatero. Não é um retangulo, e sim um trapezio, porque os membros posteriores são menos afastados que os anteriores, de modo que, vistos de frente ou de trás, os primeiros aparecem no intervalo dos ultimos. Quando o animal está em estação livre, o apoio se faz sôbre três membros e a báse é representada por um triangulo.

\section{Resultante de um sistema de forças}

A resultante de um sistema de duas forças paralelas e do mesmo sentido $\left(\mathrm{F}\right.$ e $\left.\mathrm{F}^{\prime}\right)$, aplicadas à extremidade de uma réta inflexivel $(\mathrm{AB})$, é igual à soma das componentes, do mesmo sentido e paralela a sua direção. $\mathrm{O}$ ponto de aplicação $(\mathrm{C})$ da resultante divide a réta $\mathrm{AB}$, em dois segmentos inversamente proporcionais à intensidade das componentes (Fig. 2).

Graficamente, o ponto de aplicação da resultante é determinado do seguinte modo: invertem-se as posições das forças componentes, troca-se o sentido de uma delas e unem-se as extremidades das novas forças.

A réta $f f^{\prime}$ encontrará a réta $A B$ no ponto $C$, que a divide em dois segmentos $A C$ e $C D$, inversamente proporcionais às forças $F$ e $F^{\prime}$.

Com efeito:

$$
\begin{aligned}
& \mathrm{F} \times \mathrm{CB}=\mathrm{F}^{\prime} \times \mathrm{AC} \\
& \frac{\mathrm{F} \times \mathrm{CB}}{\mathrm{AC}}=\mathrm{F}^{\prime} \\
& \frac{\mathrm{CB}}{\mathrm{AC}}=\frac{\mathrm{F}}{\mathrm{F}} \quad \text { (1) Q.E.D. }
\end{aligned}
$$

Ora, $\mathrm{CB}=\mathrm{AB}-\mathrm{AC}$. Substituindo êste valor na equação (1), teremos : 


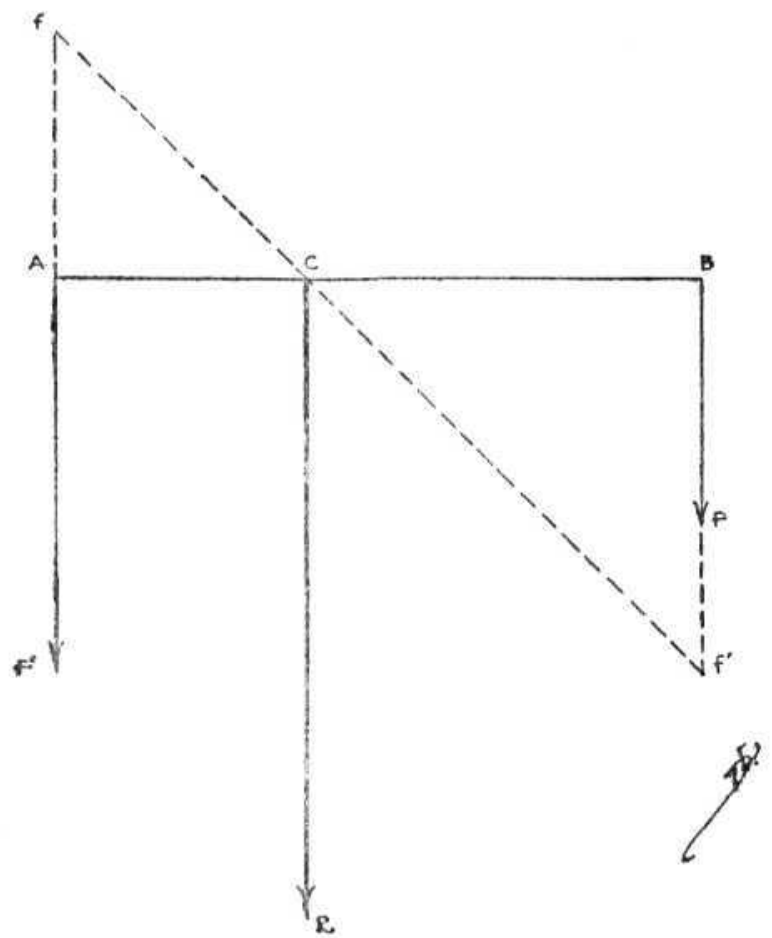

Fig. 2-Representação gráfica da resultante de um sistema de forças paralelas

$$
\begin{gathered}
\frac{A B-A C}{A C}=\frac{F^{\prime}}{F} \\
F(A B-A C)=F^{\prime} \times A C \\
F \times A B-F \times A C=F^{\prime} \times A C \\
F \times A B=A C\left(F+F^{\prime}\right) \\
A C=\frac{F \times A B}{F+F^{\prime}}
\end{gathered}
$$

Transportando êsse sistema de forças para o corpo do cavalo (Fig. 3), estando êste em estação forçada em posição, o pêso da parte anterior do corpo será representado pela força $F^{\prime}$, cujo ponto de aplicação (A) deve estar no meio da réta que une os centros dos cascos dos membros anteriores.

De modo análogo, o pêso da parte posterior do corpo será representado pela força $F$, cujo ponto de aplicação (B) deve estar no meio da réta que une os centros dos cascos dos membros posteriores.

O comprimento da réta $A B$ é igual ao da báse de sustentação. Conhecendo-se os pesos dos trens anterior e posterior e o compri- 


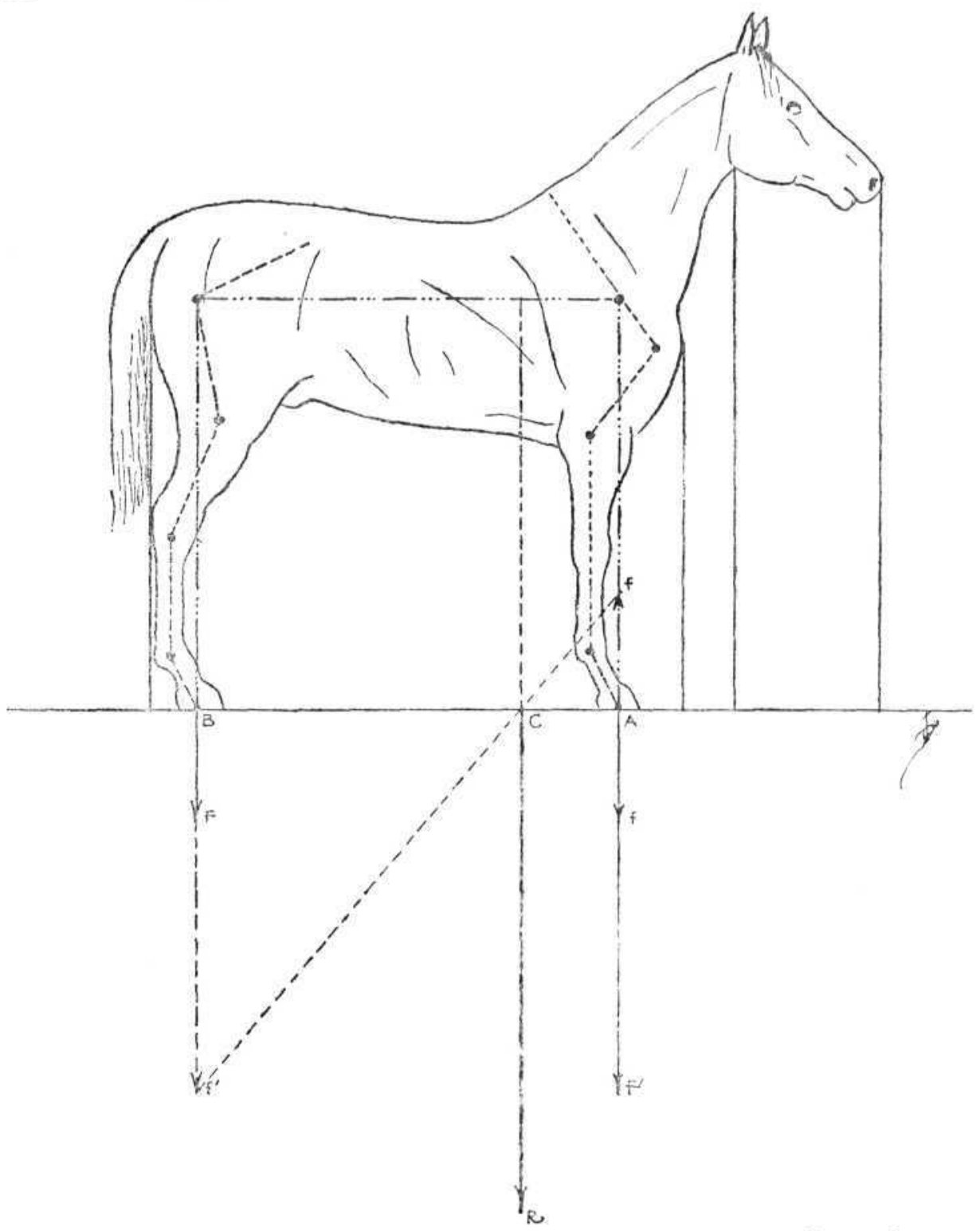

Fig. 3-Aplicação de um sistema de forças paralelas ao corpo do cavalo (Original)

mento da báse de sustentação, facil se torna determinar a que distancia do ponto $A$ irá caír o ponto $C$ (ponto de aplicação da resultante $R$ do sistema). A direção da resultante será a da linha de gravitação.

Reportando-nos à equação $(2)$, o ponto $C$ distará, do ponto de aplicação da resultante dos membros anteriores, um comprimento igual 
ao produto do pêso do trem posterior pelo comprimento da báse de sustentação dividido pelo pêso total do animal.

$$
\mathrm{AC}=\frac{\mathrm{F} \times \mathrm{AB}}{\mathrm{F}+\mathrm{F}^{\prime}}
$$

\section{Equilibrio}

Duas ou mais forças estão em equilíbrio quando, aplicadas a um mesmo corpo, não alteram seu estado de repouso ou de movimento.

Para que seja possivel o equilíbrio de um corpo apoiado sôbre um plano, é preciso que a resultante do sistema de forças aplicado a êsse corpo passe pelo interior da báse de sustentação.

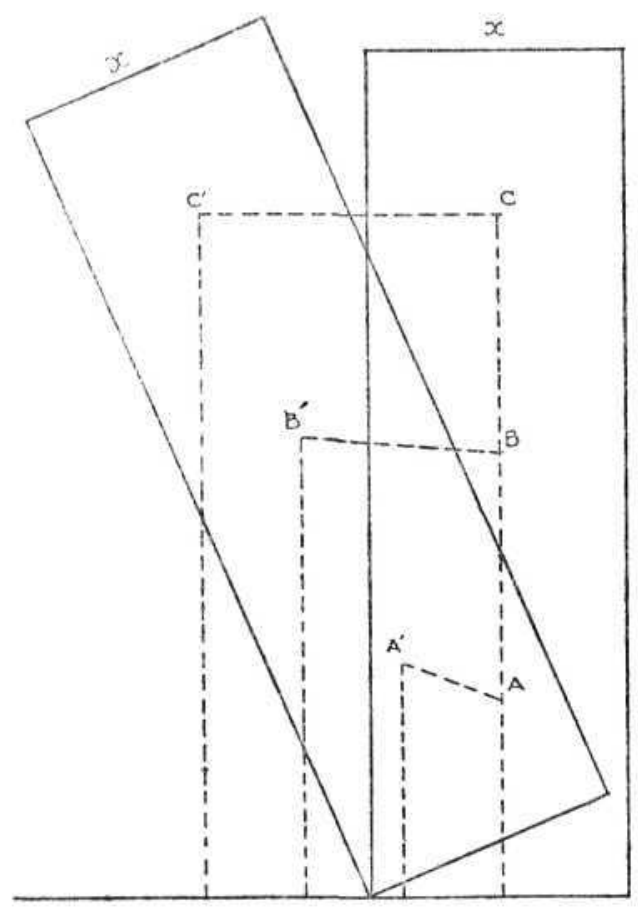

Fig. 4-Equilíbrio de um solido geometrico (E. MARCHI)

O equilíbrio poderá ser estavel ou instavel. O equilíbrio indiferente não interessa diretamente ao caso que óra estudamos. Será estavel se, deslocando-se o corpo por uma força, êle volta a sua posição inicial quando ela deixa de agir. Nêste caso, a linha de gravitação estará sempre no interior da báse de apoio. Será instavel quando 
não fôr possivel realizá-lo senão com auxilio de uma força extranha, caindo a linha de gravitação, neste caso, fóra da báse de apoio.

A estabilidade do equilíbrio será tanto maior: 1) quanto mais proximo do sólo estiver o centro de gravidade; 2) quanto mais longa e principalmente mais larga fôr a báse de sustentação; 3) quanto mais proximo do centro da báse caír a linha de gravitação.

1) Se imaginarmos um sólido (Fig. 4), cujo centro de gravidade possa ser transportado do ponto $A$ para $B$ ou $C$, e o deslocarmos da posição $x$ para $x^{\prime}$, verificaremos que sua estabilidade será tanto maior quanto mais baixo estiver o centro de gravidade. Com efeito, se êste ponto estiver em $A$, irá ocupar o ponto $A^{\prime}$ quando o corpo fôr deslocado para a posição $x^{\prime}$. A vertical baixada do centro de gravidade ao sólo cairá na projeção da báse e o equilíbrio será estavel. Se o centro de gravidade estiver em $B$, passará a ocupar o ponto $B^{\prime}$ e a linha de gravitação cairá fóra da projeção da báse, sendo o equilíbrio instavel. Com maior razão, a instabilidade seria ainda mais acentuada se o centro de gravidade estivesse em $C$.

O mesmo se verifica relativamente aos animais de tração e os de velocidade, porquanto o braquimorfismo dos primeiros $\mathrm{se}^{\prime}$ contrapõem ao dolicomorfismo dos segundos. Aqueles, tendo o esterno mais proximo do sólo, apresentam o centro de gravidade em posição mais baixa que nêstes, o que lhes assegura maior estabilidade. Os animais de corrida, tendo os membros mais longos, terão o centro de gravidade em posição mais elevada e, portanto, menor estabilidade. De fáto, já é um axioma a proposição estabelecendo que «a instabilidade do equilíbrio de um andamento qualquer nos dá a medida de sua velocidade». Efetivamente, nos andamentos em que o deslocamento do centro de gravidade determina maior probabilidade de quéda do animal, êste desloca seus membros com maior precipitação e amplitude, afim de evitar a quéda. Como disse DugÉs, a marcha é uma quéda indefinidamente retardada.

2) A maior amplitude da báse de sustentação, tanto em largura como em comprimento, aumenta a estabilidade do equilíbrio, pois mais dificilmente a linha de gravitação, em suas oscilações, cairá fóra da báse ou de sua projeção.

Os animais de tração têm o corpo mais volumoso, membros mais afastados e, consequentemente, uma báse de sustentação mais ampla. São, portanto, mais estaveis que os animais de velocidade, cuja báse de sustentação é mais estreita em virtude do menor desenvolvimento transversal do corpo.

3) Deduz-se, do item precedente, que a estabilidade será tanto maior quanto mais afastada dos limites da báse caír a linha de gravi- 
tação. Ora, o ponto mais distante dos limites da báse será, forçosamente, o centro do quadrilatero de apoio. Portanto, a estabilidade será tanto maior quanto mais proximo daquele ponto caír a linha de gravitação.

\section{DESLOCAMENTO DO CENTRO DE GRAVIDADE}

Os musculos, pelas suas contrações ou distenções, atuam sôbre o esqueleto, cuja ação é unicamente passiva, podendo determinar atitudes, movimentos sobre o lugar, andamentos e saltos.

Atitudes são as diferentes posições que o animal pode tomar em repouso; movimentos sôbre o lugar são os que não deslocam o corpo em sentido horizontal, estando muito proximo dêles os que o deslocam muito lentamente; andamentos são os movimentos que determinam a locomoção ou progressão do animal; saltos são os movimentos que deslocam o corpo do sólo, projetando-o a uma certa altura e distancia. Não incluimos os saltos entre os movimentos que se executam sôbre o lugar, como o fazem Lesbre, ZwaEnepoel, etc., porque êle se efetúa, geralmente, no decurso de um andamento e porque o deslocamento se faz a uma distancia relativamente grande, principalmente em se tratando do salto em extensão. A. Magliano cita o cavalo Vainhope que, montado, efetuou um salto de 10,34 metros em extensão. O proprio ZwAENEPOEL se refere aos cavalos The Chandler e Skyscraper, que executaram, respetivamente, saltos de 12 metros em extensão e 2,51 metros em altura.

\section{Atitudes}

Distinguimos a atitude de pé ou estação, a atitude deitada ou decubito e a atitude sentada. Destas, a unica que interessa ao nosso estudo é a estação, que pode ser forçada ou livre. Na estação forçada, os quatro membros estão em apoio no sólo e o pêso do corpo se exerce,

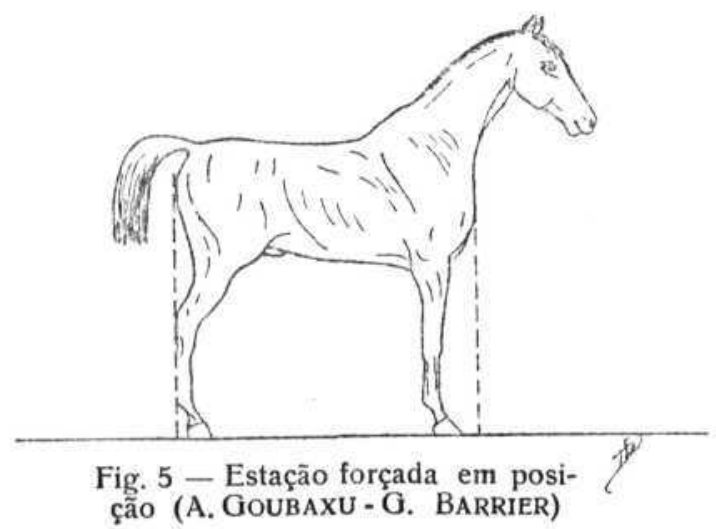


de acôrdo com o que já dissémos, mais sôbre os membros anteriores, que sôbre os posteriores, porém igualmente em cada membro do bipede anterior e posterior. Distinguimos a estação forçada em posição (Fig. 5), quando os membros conservam seus aprumos normais; juntada ou

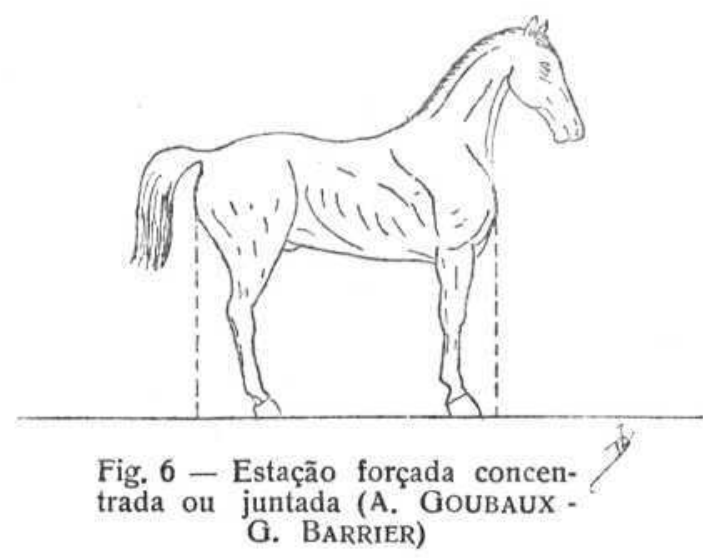

concentrada (Fig. 6), quando os membros anteriores e posteriores se aproximam, diminuindo a báse de sustentação e, portanto, a estabilidade; acampada, extendida ou desconcentrada (Fig. 7), quando os membros anteriores e posteriores se afastam, respetivamente, para deante

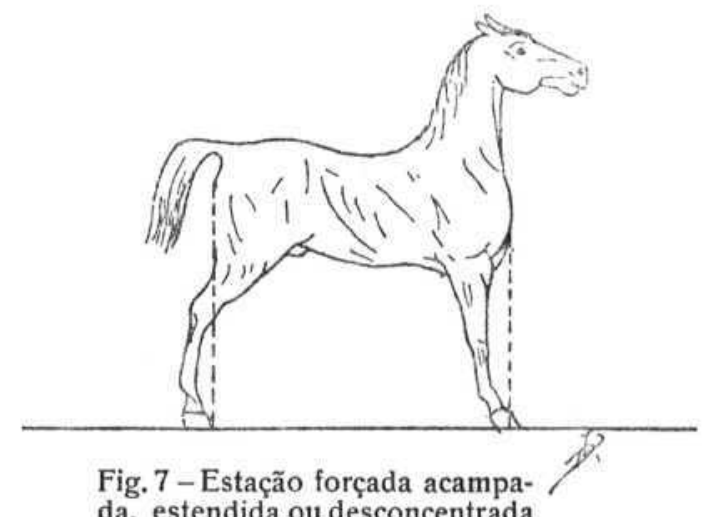

da, estendida ou desconcentrada

(A. Goubaux - G. Barrier)

e para trás de suas linhas de aprumo, aumentando assim a báse de sustentação. A linha de gravitação terá sua situação normal, isto é, ocupará o lugar da resultante do sistema de forças representado pelo pêso do trem anterior e posterior.

Na estação forçada juntada ou concentrada, o pescoço tende à verticalidade e a cabeça é projetada para trás de sua posição normal, o 
que determina o deslocamento do centro de gravidade para a parte posterior e, consequentemente, diminuição do pêso do trem anterior. O cavalo toma esta atitude quando se prepara para saltar ou empinar, sendo, portanto, de pequena duração.

$\mathrm{Na}$ estação forçada acampada, extendida ou desconcentrada, a cabeça e o pescoço são projetados para trás, fazendo com que a linha de gravitação se desloque para o centro da báse, dando assim maior estabilidade ao animal. E', porém, artificial e fatigante para o cavalo, em virtude da posição forçada da coluna vertebral. Os vendedores fazem o cavalo tomar esta atitude quando desejam encobrir algum defeito de aprumo ou de proporções.

Estas modalidades de estação são as que momentaneamente podem tomar os cavalos de aprumos normais. E' em estação forçada em posição que se devem estudar os aprumos e caracteres exteriores dos animais.

$\mathrm{Na}$ estação livre, atitude que o animal toma quando em repouso, pois que exige um esforço muscular reduzido, o apoio é tripedal. O membro em descanço, que é quasi sempre um posterior, acha-se semiflexionado, apoiando-se no sólo, pela pinça. Esta disposição faz com que a garupa do lado do membro em repouso fique mais inclinada que a oposta. A báse de sustentação passa a ser tripedal posterior, direita ou esquerda, conforme o membro que permanece em apoio. $\mathrm{O}$ repouso de um membro anterior raramente se verifica, pois os raios osseos são mantidos em posição por orgãos passivos, sem auxilio dos musculos, sendo o pêso do corpo suportado sem cansaço para os membros toracicos. Periodicamente o animal muda o membro posterior em apoio, afim de repousá-lo, pois, nêstes, a sustentação é feita, em parte, pela interferencia dos musculos extensores da coxa e, entre eles, em particular pelo gluteo médio, coadjuvado principalmente pelo parameral, semi-tendinoso e semi-membranoso (L. Preziuso).

Estando a linha de gravitação mais proxima dos membros anteriores e sendo êstes mais afastados entre si que os posteriores, a estabilidade será maior quando um membro posterior estiver em repouso do que quando um anterior, pois a báse de apoio será maior no primeiro caso.

\section{Movimentos sôbre o lugar}

Entre êstes movimentos, distinguimos o empino e o coice.

1. ${ }^{\circ}$ Empino - E' o movimento que o animal executa elevando a parte anterior do corpo, permanecendo alguns instantes apoiado sómente sôbre os membros posteriores. Para executá-lo, o animal abaixa o pescoço e a cabeça e projeta-os, em seguida, para trás, de modo a 
diminuir o pêso da parte anterior do corpo. Ao mesmo tempo, aproxima os membros anteriores dos posteriores e empina, elevando o trem anterior. Esta posição não poderá ser mantida senão por alguns instantes, em virtude de sua extrema instabilidade e dos violentos esforços musculares e articulares exigidos. Com efeito, o centro de gravidade estará situado muito alto e a báse de sustentação ficará reduzida a u'a linha, que une os membros em apoio. O garanhão executa o empino ou encabritamento no áto da cópula. Chaves DE Lemos cita o cavalo Comodo, de 20 anos de idade, que empinava logo que via a égua, caminhando assim até atingí-la. Ha animais, especialmente adestrados, que conseguem permanecer algum tempo nessa posição (equilibrio instavel), mas são forçados a deslocar a báse de apoio para que a linha de gravitação não se afaste além de um determinado limite. Quando o empino é exagerado e a linha de gravitação ultrapassa, para trás, a báse de apoio, o animal cái sôbre a coluna vertebral. Neste caso, diz-se que êle boleia.

2. ${ }^{\circ}$ Coice - O coice, contrariamente ao empino, é a elevação da parte posterior do corpo, com distensão rapida das extremidades pélvicas. Na fáse de preparação, o cavalo abaixa a cabeça para descarregar o pêso do trem posterior e acampa-se sôbre os membros anteriores. Segue-se a fáse de execução. Na primeira fáse, o centro de gravidade é deslocado para frente, porém, a linha de gravitação nunca atinge a báse de sustentação que, nêste caso, tambem é representada por u'a linha unindo os membros em apoio. A instabilidade é, portanto, completa, o que obriga o animal a apoiar os membros posteriores logo após a sua distensão. O burro e o jumento, na fáse de preparação, abaixam mais a cabeça, colocando-a entre os membros torácicos e ficam debruçados em vez de acampados. Isto permite que o centro de gravidade se aproxime mais da linha de sustentação e que o movimento de distensão seja executado mais para o alto. O coice é simples quando o movimento é executado com um só membro; nêste caso, não ha elevação do trem posterior. $\mathrm{O}$ coice simples pode ser dado para a frente, para trás ou para o lado (coice de vaca). Éste ultimo é frequente na especie bovina, em virtude da falta do ramo pubiano do ligamento coxo-femural. Para executar o coice simples, o animal abaixa ligeiramente a cabeça, com o fim de deslocar para a frente o centro de gravidade, e projéta um dos membros posteriores. A báse de sustentação será, então, tripedal posterior, do mesmo modo que na estação livre.

\section{Andamentos}

Dá-se o nome de andamentos às diversas modalidades de progressão ou de locomoção dos animais terrestres. Têm sido estudados 
particularmente no cavalo, em virtude de ser êste animal o que está mais em contacto com o homem e o que maior soma de serviços lhe presta.

Durante a locomoção, os animais movimentam seus membros, que passam, sucessivamente, por duas fáses: apoio e suspensão. $\mathrm{O}$ apoio é o periodo durante o qual o membro está em contacto com o sólo, sustentando o pêso do corpo, que se desloca em torno do pé. Inicia-se pelo «pôr» e termina pelo «apoiar». A suspensão é a fáse durante a qual o membro está levantado do sólo, oscilando, no sentido da progressão do animal, em torno de um ponto denominado centro de suspensão. A suspensão começa pelo «levantar» e termina pelo «suster».

«Pôr», «apoiar», «levantar», "suster», são as 4 fáses pelas quais passa um membro ao executar um passo.

A distancia percorrida, depois que cada membro passou uma vez pelos periodos de apoio e de suspensão, constitue um passo completo.

Batida é o ruido particular produzido pelo "pôr» de cada membro. De acôrdo com o numero de membros que se associam na execução dos andamentos, ouvem-se duas, três ou quatro batidas em cada passo completo.

Pégádas são as impressões que os pés deixam no sólo. O conjunto dessas impressões constitue a pista. Esta será simples, quando as pégádas dos pés posteriores coincidirem com as dos anteriores do mesmo lado. Nêste caso, diz-se que o animal se cobre ou faz sobrepégádas. A pista será dupla, quando as pégádas dos pés posteriores ficarem adeante ou atrás das dos anteriores correspondentes. No primeiro caso, diz-se que o animal se adeanta ou faz ultra-pégádas e, no segundo, que se descobre ou faz retro-pégádas.

Notação é a representação grafica de um andamento. Ela póde representar simplesmente a pista deixada pelo animal ou figurar os sucessivos periodos de apoio e de suspensão.

Existem diversos métodos de notação, dentre os quais se destacam os de Vincent e Goiffon, Marey, Smith, etc..

$\mathrm{O}$ primeiro, denominado escala odocronométrica de VINCENT e GolfFon, consiste em 4 linhas horizontais, paralelas, $A D, P E, A E$ e $P D$ (Fig. 8), cortadas por traços verticais equidistantes entre sí, marcando cada um dêles os diferentes tempos do andamento. Cada espaço compreendido entre os traços verticais é dividido em três instantes por linhas ponteadas. Isto constitue a representação de um passo completo. Os apoios de cada membro são representados por traços cheios 
sôbre as linhas correspondentes e os periodos de suspensão dos membros, por linhas pontilhadas. A figura abaixo, retirada de Goubaux et BARRIER, é a notação do andamento passo.

O metodo de MAREY compõe-se de duas linhas horizontais e paralelas, sôbre as quais são projetadas as curvas traçadas pelo aparelho registrador do mesmo autor. Pela figura 9, vemos, em $M A$, a li-

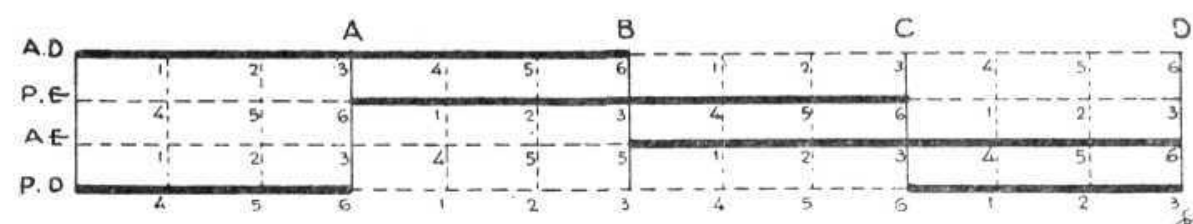

Fig. 8 - Notação do passo pelo metodo de Vincent e Goifion (Â. Goubaux - G. BARRIER)

nha abcissa das curvas dos membros anteriores e em $M P$, a dos posteriores. As curvas dos membros direitos estão representadas em traços cheios e as dos esquerdos, em traços finos. As ordenadas marcam o começo e o fim do apoio de cada membro. Convencionou-se que, abaixo de cada traço horizontal, seriam representados, em claro (D), os membros direitos e, acima e em escuro (E), os esquerdos. O com-

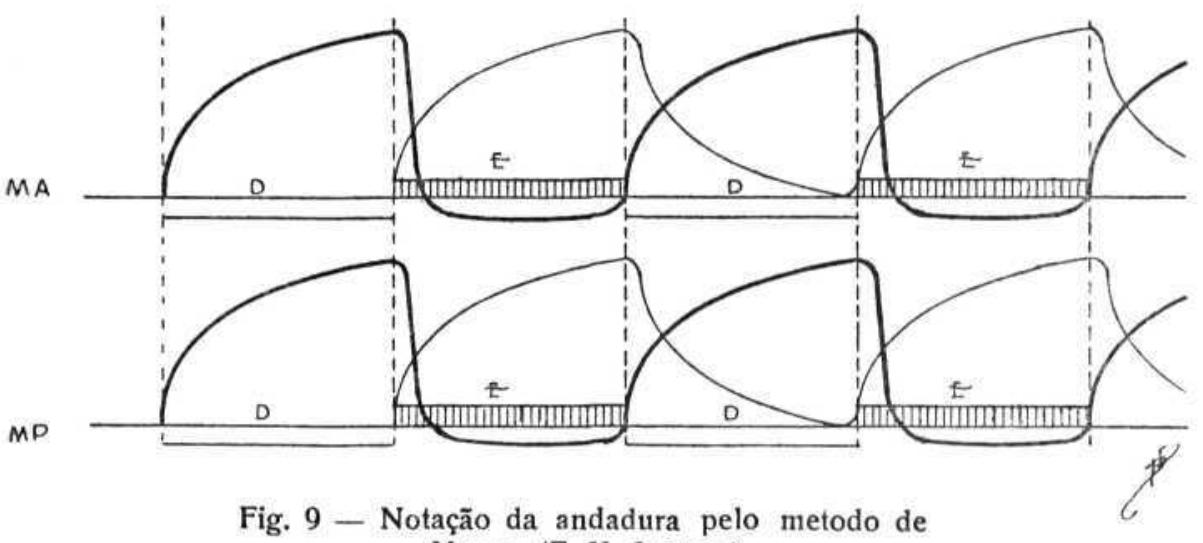
Marey (F. X. LESBRE)

primento dos traços claros e escuros é proporcional à duração do apoio do membro correspondente.

O metodo adotado por SмIтH consiste em representações esquematicas do corpo do cavalo, nas quais a parte mais estreita corresponde à cabeça e, em cujo interior, os membros em apoio são representados por pontos. 
Adotámos, no presente trabalho, conforme as conveniencias do momento, o metodo de Marey e o de Smith. Nas notações pelo primeiro dêstes processos, os algarismos romanos, no interior das figuras, representam os membros em apoio; os arabicos indicarn, em frações de 1/64 de segundo (*), a duração dos periodos correspondentes. Em algumas destas notações, os tempos que separam as batidas sucessivas são anotados abaixo das figuras.

Para melhor estudar os deslocamentos do centro de gravidade, durante a locomoção, procurámos reunir, em uma mesma notação reproduzindo a pista, as oscilações horizontais e verticais daquele centro. Estas oscilações são figuradas esquematicamente, apenas para dar uma idéa dos deslocamentos do centro de gravidade.

\section{FISIOLOGIA DA LOCOMOÇÃO}

A maquina animal se compõe de uma parte ativa - os musculos, e de uma parte passiva - o esqueleto.

Os musculos locomotores, pelas suas contrações, atuam sôbre o esqueleto, modificando a angulação das alavancas osseas.

$\mathrm{Na}$ parte ativa, reconhecemos musculos extrinsecos e intrinsecos. Os primeiros tomam inserção sôbre o tronco e sôbre os membros, podendo ser propulsores ou retropulsores. Os segundos se inserem sôbre dois raios do mesmo membro e são tambem propulsores ou retropulsores, principalmente nos membros posteriores, em virtude da sólida articulação do coxal com o sacro.

Os musculos extrinsecos propulsores podem estar situados adeante ou atrás dos membros. Quando são situados adeante, a inserção nos membros é feita acima do centro de suspensão dêstes ultimos (angular da espádua -1 , romboide cervical -2 , trapezio cervical -3 e gluteos - 4); quando situados atrás, abaixo do centro de suspensão (grande dorsal -5 , peitoral profundo -6 e isquiotibiais -7 ) (Fig. 10).

O inverso se verifica com os musculos extrinsecos retropulsores. Quando se inserem no tronco, adeante dos membros, a inserção nestes é feita abaixo de seu centro de suspensão (mastoide-humeral -8 e psôas - 9); quando atrás dos membros, a inserção nestes é feita acima do seu centro de suspensão (trapezio dorsal - 10) (Fig. 10).

A progressão do animal se inicía pelo levantar de um membro anterior, o que se efetúa pela ação dos musculos extrinsecos que o sustêm. Para aliviar do pêso do corpo o membro que se eleva, os peitorais opostos se contráem, deslocando para seu lado o centro de gravidade. Logo em seguida, pelas suas contrações, os musculos ex-

(•) Esta unidade de tempo foi adotada, no presente trabalho, porque todas as filmagens foram fei tas, como já dissémos de início, com 64 imagens por segundo. 
trinsecos retropulsores solicitam o membro para a frente e, distendendo a espádua, aumentam o comprimento do membro, facilitando assim seu apoio sôbre o sólo. O balancear do membro para a frente é auxiliado, principalmente nos andamentos lentos, pelo seu proprio peso (movimento de pêndulo). O apoio do membro é coadjuvado pelos musculos intrinsecos, que distendem todas as articulações, em virtude da solidariedade de movimentos existentes entre elas. Neste momento, entram em ação os musculos extrinsecos propulsores que, contraíndo-se, levam o corpo sôbre o membro, iniciando-se do lado oposto, os mesmos movimentos referidos.

Quando o membro está levantado e os musculos extrinsecos propulsores se contráem, é aquele levado para trás, apoiando-se no sólo.

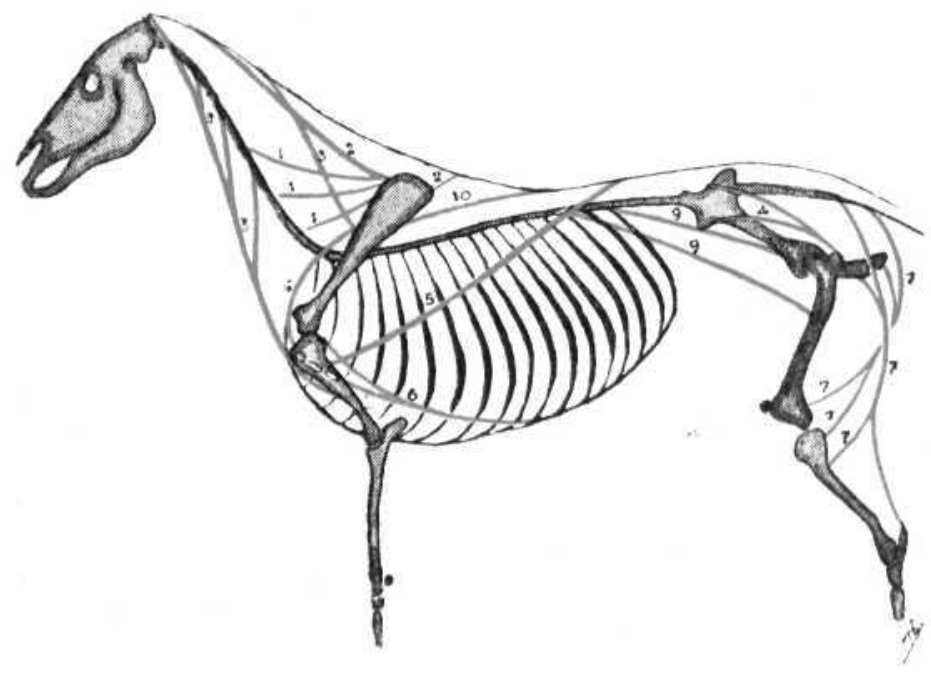

Fig. 10 - Representação dos musculos locomotores (Adap. W. Ellenberoer - H. Baum)

A contração dos musculos extrinsecos retropulsores leva, então, o corpo sôbre o membro e o animal recúa. Fenomenos identicos se verificam nos membros posteriores. Um dêstes é levantado pela contração dos musculos que determinam a flexão do femur sôbre o coxal, isto é, pelos musculos extrinsecos grande psôas e iliaco, coadjuvados, principalmente, pelo réto anterior da coxa que, embora sendo intrinseco, tem ação direta no levantamento do membro, graças à íntima união do coxal com o sacro. Como a terminação do grande psôas e iliaco se faz muito proximo da articulação coxo-femural (pequeno trocanter), êstes musculos têm mais ação de alavancas de velocidade, enquanto que o réto anterior da 
coxa, inserindo-se na tuberosidade anterior da tibia, atúa mais como alavanca de força.

Quando o membro é levantado, o apoio se torna tripedal e, para que o equilibrio se mantenha, o centro de gravidade é deslocado para o lado oposto pela contração dos musculos laterais e mediais do membro em sustentação. Ao mesmo tempo que o membro é levantado, os musculos extrinsecos repropulsores (iliaco e psôas) lévam-no para a frente e o apoio se dá pela intervenção dos musculos intrinsecos. E' neste momento que atuam os extrinsecos propulsores (pequeno glúteo, glúteo médio e isquio-tibiais), que levam o corpo sôbre o membro. Do lado oposto se iniciam, então, os mesmos movimentos, havendo deslocamento do centro de gravidade para o lado do membro em apoio. Se o membro estiver levantado, será levado para trás pela contração dos musculos extrinsecos propulsores que, auxiliados pelos intrinsecos, determinam o apoio posterior. Se, agora, os extrinsecos retropulsores atuarem, o tronco será levado sôbre o membro e o animal recuará.

\section{FISIOLOGIA DA TRAÇÃO}

A disposição diferente dos diversos raios osseos, que constituem os membros anteriores e posteriores, e a menor distancia que separa os primeiros do centro de gravidade indicam a função diversa, mas não exclusiva, de cada bipede. Os membros anteriores, ligados ao tronco por meio de musculos e laminas fibrosas elasticas, são quasi rétos e verticais e têm, sobretudo a função de suportar o pêso do corpo e atenuar as reações produzidas pela locomoção.

Os posteriores, solidamente ligados à coluna pela articulação sacro-iliaca, sendo constituidos de alavancas osseas com angulos alternativamente abertos para deante e para trás, sôbre as quais atuam musculos poderosos que modificam sua angulação, são mais propulsores que propriamente sustentadores.

A origem do impulso tem sido muito discutida por diversos AA., entre os quais Colin, Price, Lafosse, Barthez, Le Hello, etc.. Êste ultimo, por meio de um sistema de molas representando os musculos, conseguiu demonstrar:

a) que o impulso se inicia antes do meio do apoio;

b) que são os musculos isquio-tibiais que mais poderosamente contribuem para a impulsão;

c) que os musculos gluteos, isquio-tibiais e triceps crural, cuja ação se transmite aos gastro-cnemios e flexores superficiais pelas suas bridas tendinosas, garantem a extensão dos raios inferiores dos membros; 
d) que o pêso do corpo é necessario à propulsão, do mesmo modo que a rigidês da coluna vertebral;

e) que os musculos grande-peitorais tambem têm ação impulsiva, o que vem provar a não exclusividade da função propulsiva dos membros pélvicos.

O início da tração se caracteriza pelo deslocamento do centro de gravidade para trás, o que se dá pela pressão da coelheira que se prende ao veículo a tracionar. Em consequencia dêste deslocamento, o trem posterior sofre uma sobre-carga, para a qual tambem contribue a contração dos musculos isquio-tibiais e gluteos, que tende a elevar o centro de gravidade e o trem anterior, facilitando os movimentos do bipede toracico. Para que a locomoção se inicie é preciso que o centro de gravidade ocupe uma posição o mais anterior possivel, o que o animal consegue distendendo a cabeça e o pescoço, dispondo os membros obliquamente para trás e flexionando os anteriores. Nêste momento (Fig. 11, Est. I), torna-se evidente:

a) o abaixamento do trem posterior e maior obliquidade da garupa, em consequencia da contração dos musculos isquio-tibiais;

b) o apoio dos membros em pinça, em virtude da energica solicitação dos tendões dos musculos flexores profundos das falanges.

$\mathrm{O}$ escorregamento para trás que, às vezes, conforme a natureza do terreno, se observa nos membros anteriores, é provocado pela menor pressão dêstes membros sôbre o sólo, em consequencia da diminuição do pêso do trem anterior; pela menor superficie de contacto, visto o apoio ser feito em pinça; e pelas contrações dos musculos extrinsecos propulsores, em especial o peitoral e o grande dorsal, que procuram levar o membro para trás.

Depois de iniciada a locomoção, o deslocamento dos membros não é grande, pois o apoio se faz verticalmente, para manter o centro de gravidade em posição anterior.

\section{DIVISÃO DOS ANDAMENTOS (*)}

$\mathrm{O}$ andamento do cavalo, como dos outros quadrupedes, pode ser comparado ao deslocamento de dois bipedes, um atrás do outro (DuGÉs). Do acôrdo ou desacôrdo dos movimentos dos bipedes laterais, resultam as diversas modalidades dos andamentos. Assim, quando os membros laterais se apoiam ou se sustêm ao mesmo tempo, o andamento recebe o nome de andadura. Quando se associam em bipedes diagonais e dois

(*) Os andamentos que a seguir serão estudados são a andadura, o trote, o galope, o passo e as diferentes modalidades dêstes andamentos. Os demais, bem como as denominaçôes especiais usadas em certas regiôes do Brasil, serão estudados em trabalhos que estão sendo feitos. 
a dois se apoiam ao mesmo tempo, o andamento é o trote. Quando os membros de um bipede diagonal se dissociam, enquanto os do outro se apoiam ao mesmo tempo, recebe a denominação de galope. A dissociação dos apoios dos quatro membros constitue o passo.

Os andamentos podem ser naturais, adquiridos ou artificiais. São ainda marchados ou saltados, laterais ou diagonais, simetricos ou asimetricos, a dois, tres ou quatro tempos, alongados ou encurtados, altos ou baixos, etc..

Os andamentos naturais são os que o cavalo emprega, naturalmente, em sua locomoção. Tais são o passo, o trote e o galope. Os adquiridos, andadura, $\left(^{*}\right)$ passo relevado e trote de corrida, são os que ele executa depois de uma educação especial. A faculdade de executar êstes andamentos pode ser transmitida hereditariamente (ZWAENEPOEL) (?).

Os artificiais, como o "piaffer», "passage», passo espanhol, etc., são andamentos de alta escola, executados por animais especialmente adestrados.

Sempre que, durante a locomoção, o animal estiver em contacto permanente com o sólo, o andamento será marchado: passo e andadura. Quando houver um periodo de suspensão, isto é, um momento em que o cavalo fica completamente destacado do terreno, o andamento será saltado: trote e galope.

Andamentos laterais são os que se efetúam pelo deslocamento sucessivo dos bipedes laterais: andadura. Diagonais são aqueles que se executam pelo deslocamento dos bipedes diagonais: passo, trote e galope.

Simetricos são os andamentos em que o apoio ou a suspensão de cada um dos membros se efetúa em intervalos iguais, de modo que os membros direitos e esquerdos se sucedem, alternativamente, em seu apoio anterior: andadura, passo e trote. Asimetricos são aqueles nos quais um membro direito ou esquerdo sempre se põe em apoio adeante do outro: galope. No galope à direita, é sempre o membro direito, anterior ou posterior, que se apoia adeante do esquerdo; no galope à esquerda, o contrário se verifica.

Diz-se que um andamento é a dois tempos quando, em cada passo, ouvem-se duas batidas distintas, indicando a associação de bipedes laterais ou diagonais: andadura e trote. E' a tres tempos, quando se ouvem tres batidas, isto é, quando um bipede é associado e o outro é dissociado, como no galope. E' a quatro tempos, quando cada mem-

(") A andadura é considerada, pelos diversos AA., ora como andamento natural ora como adquirido. É natural, nos animais em que ha dolicomorfismo dos membros e braquimorfismo do tronco, como potros, camelos, girafas, etc, porque, se nêstes animais, os movimentos dos membros laterais fossem dissociados, facilmente êstes se alcançariam em suas oscilações. Algumas raças de cavalos, entre elas a Mangalarga, a Campolina, os Andadores americanos, etc., têm grande facilidade em tomar a andadura, que pode, mesmo, ser considerada um andamento naturai. 
bro se apoia isoladamente, como se observa no passo e em algumas variedades do trote e do galope.

A divisão em andamento alongado ou encurtado diz respeito ao comprimento do passo. Podem ainda ser altos ou baixos, conforme o deslocamento do pé, em sua fáse de suspensão, seja feito longe ou proximo do sólo.

\section{ANDAMENTOS EM PARTICULAR}

\section{a) Andadura}

Definição - A andadura é um andamento natural ou adquirido, marchado, lateral, simetrico, encurtado, baixo e a dois tempos, durante o qual os bipedes laterais se sustêm e se apoiam alternativamente.

Notação - MAREY, não considerando o periodo de troca de apoio, é de opinião que o «levantar» de um bipede lateral coincide perfeitamente com o "pôr» do outro bipede. Assim sendo, a notação dêste andamento é a representada na figura 12 .

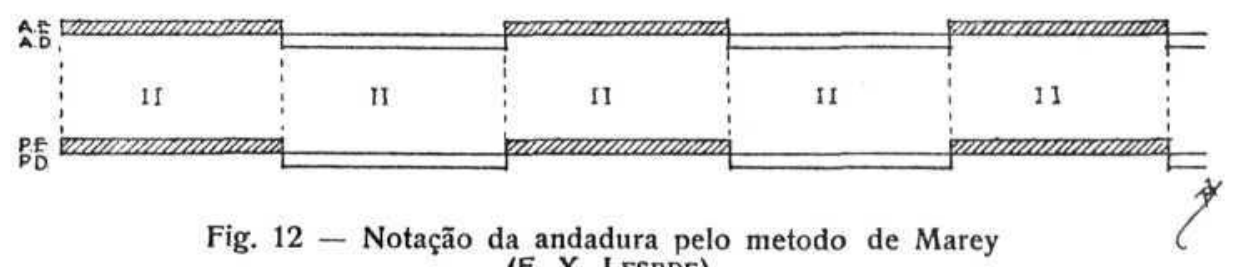
(F. X. LESBRE)

Autores ha que admitem um rapido periodo de apoio quadrupedal, entre duas batidas consecutivas, o que não pudémos observar por não ter sido possivel encontrar um animal com esta andadura tipica. Se tal animal existe, é mais razoavel admitir um apoio quadrupedal, do que supôr que o «levantar» do bipede lateral coincide exátamente com o "pôr» do outro. Tal periodo de apoio teria uma duração inversamente proporcional à velocidade da andadura.

SmIrH define a andadura como sendo «uma série rapida de passos curtos, na qual os membros laterais e diagonais são alternativamente empregados, sem periodos de suspensão completa». Segundo este modo de ver, a notação passa a ser a da figura 13 , na qual vemos que, entre dois apoios laterais, se intercalam um apoio monopedal anterior, um bipedal diagonal e um monopedal posterior.

Centro de gravidade - Na andadura normal, a base de sustentação passa de um bipede lateral a outro, de modo a tornar o equilíbrio instavel no sentido lateral, o que obriga o animal a apoiar rapidamente 
os membros em suspensão, que se movem muito proximo do sólo. $\mathrm{O}$ centro de gravidade sofre um deslocamento lateral mais pronunciado que o vertical, sendo, portanto, suaves as reações.

Dada a raridade de um animal com andadura tipica, em dois tempos, lançou-se mão, para a determinação das variações do centro de gravidade, de uma egua Mangalarga, cujo andamento (Fig. 14) será descrito mais adeante, sob o titulo de modalidade da andadura.
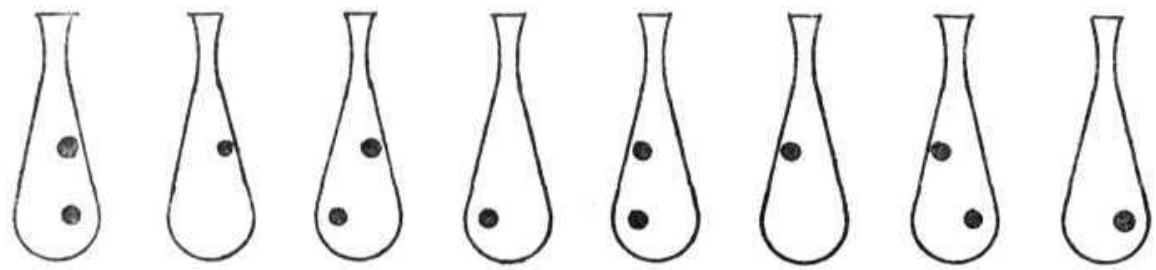

Fig. 13 - Notação da andadura, segundo Smith (F. SMITH)

O traçado do deslocamento acima referido é apenas esquematico. Para conseguí-lo, foi usado o artificio de considerar o centro de gravidade fixo no corpo do cavalo, identificando-o a um ponto tomado no cilhadouro. A escolha dêste ponto se justifica pela sua proximidade à localização do centro de gravidade anteriormente estabelecida, por ser de facil reparo em qualquer periodo da locomoção e por ser muito pouco sujeito a variações, visto estar situado sôbre uma região rigida.
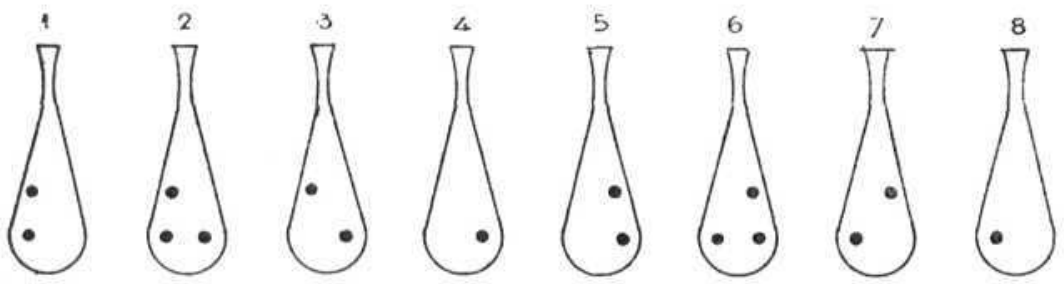

Fig. 14 - Notação de uma modalidade de andadura pelo metodo de Smith (Original)

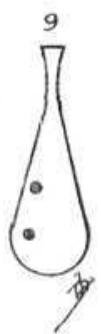

A determinação do deslocamento dêste ponto foi feita pela projeção do film, do seguinte modo: no momento da batida do membro anterior esquerdo (Fig. 14-1), foram tomadas a altura do cilhadouro e a distância de sua projeção horizontal ao meio do casco do membro anterior esquerdo. Êstes dois elementos permitiram determinar o primeiro ponto da curva (Fig. 15-1), sôbre o eixo das ordenadas. Nos quadros seguintes de apoio bipedal lateral esquerdo, foram tomadas as 
diferentes alturas do cilhadouro e as distâncias respetivas de sua projeção horizontal ao mesmo membro anterior mencionado. Êstes dados forneceram outros pontos de curva, inclusive os pontos mais alto e mais baixo desta (Fig. 15- $a$ e $b$ ). Ao ser feita a batida do membro posterior direito (Fig. 14-2), notaram-se a altura do cilhadouro e a nova distância de sua projeção horizontal ao meio do casco do mesmo membro anterior esquerdo. Com êstes dados foi determinado o ponto da curva correspondente à batida do posterior direito (Fig. 15-2). Êste membro serviu, nos quadros seguintes, de ponto de reparo fixo para determinar a distância das projeções horizontais do cilhadouro que, com as diferentes alturas dêste, deram outros pontos da curva. O mesmo foi feito nas batidas seguintes, até completar um passo.

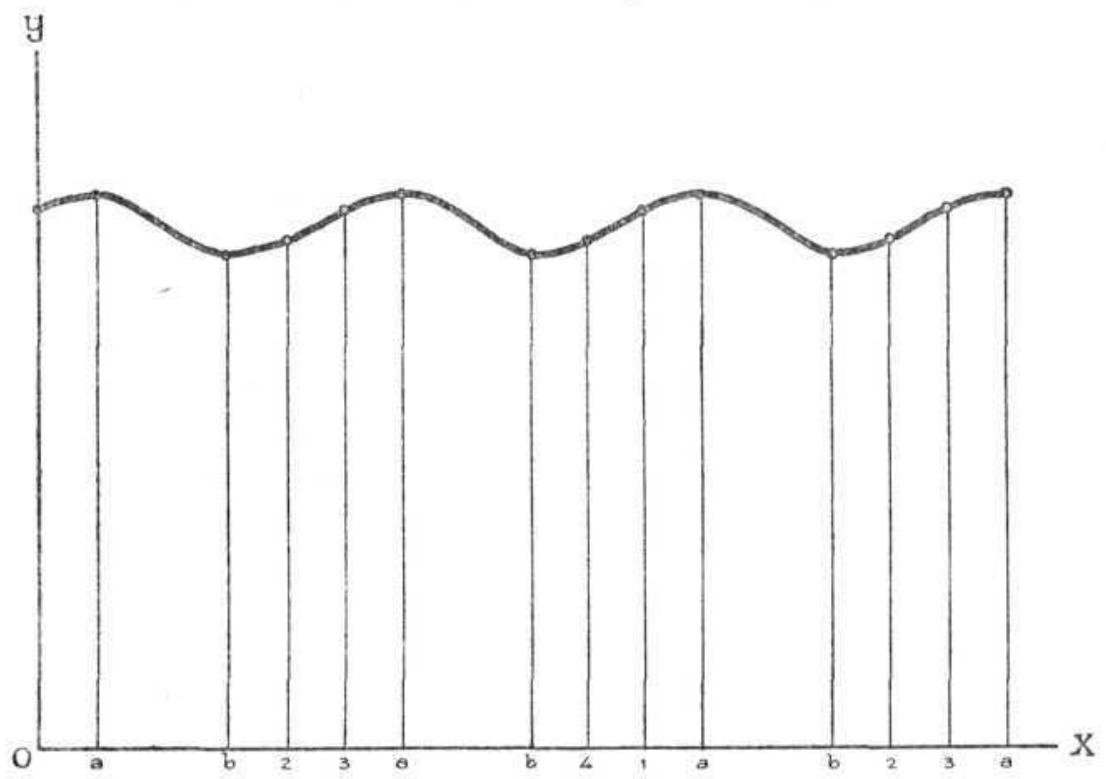

Fig. 15 - Projeção do deslocamento vertical do centro de gravidade na andadura (Original)

Dêste deslocamento foi deduzida a pista deixada pelo animal, do seguinte modo: estando o ponto do cilhadouro em uma certa posição, no momento da batida de um membro, a pégáda dêste foi determinada pela sua distância à projeção horizontal do ponto considerado. Dêste modo foi possivel associar, em uma mesma figura, a representação do deslocamento vertical e a pista do andamento em estudo.

Na figura 16, assim obtida, as linhas paralelas, em traços cheios representando as bases de apoio dos bipedes laterais, mostram que o 
animal se ultra-cobre. As curvas representativas do deslocamento vertical, não só da andadura como dos demais andamentos, não correspondem às apresentadas nos tratados. No caso presente, as curvas obtidas são suaves, em numero de duas para cada passo e não formam, como as que se observam nos autores, um angulo de inflexão em seu ponto mais baixo. Tanto êste, como o ponto mais alto, verificam-se durante os apoios bipedais laterais. A curva descrita durante o apoio lateral é mais longa que a verificada durante os apoios tripedal, bipedal diagonal e unipedal, o que coincide com a duração dêstes apoios, como será observado mais adeante.

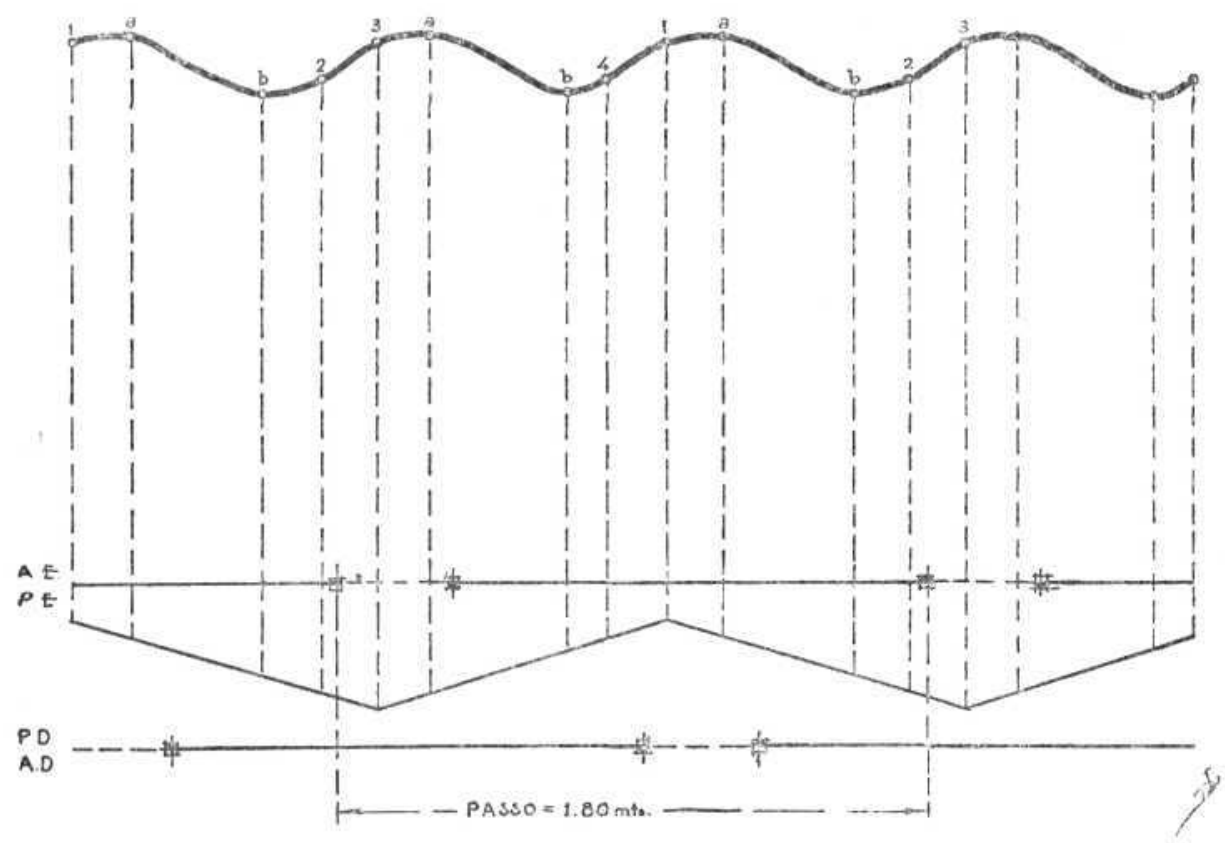

Fig. 16-Deslocamento do centro de gravidade e pista de um animal em andadura (Original)

A projeção horizontal, tambem observada na figura, em traços finos, foi deduzida teoricamente. Segundo dizem os tratados, ela descreve uma linha quebrada. A nosso vêr, é uma linha mixta, cujo ponto mais proximo da báse de sustentação bipedal lateral corresponde ao momento da batida do membro anterior do mesmo lado. Entretanto, nêste como nos demais andamentos, fazemos a representação em linhas retas, para mais facil compreensão da figura.

Modalidades - a) Andadura interrompida - E' tambem denominada desunida ou passo desunido (LEONOBLE DU TEIL). 
A andadura descrita por SMITH confunde-se com a andadura interrompida mencionada por Magliano, com a diferença que êste último não considera os apoios monopedais. Entretanto, de acôrdo com LesBre, a andadura interrompida é aquela na qual os bipedes laterais dissociam suas batidas, pondo-se o posterior em apoio pouco antes que o anterior correspondente (Fig. 17), de sorte que, em cada passo,

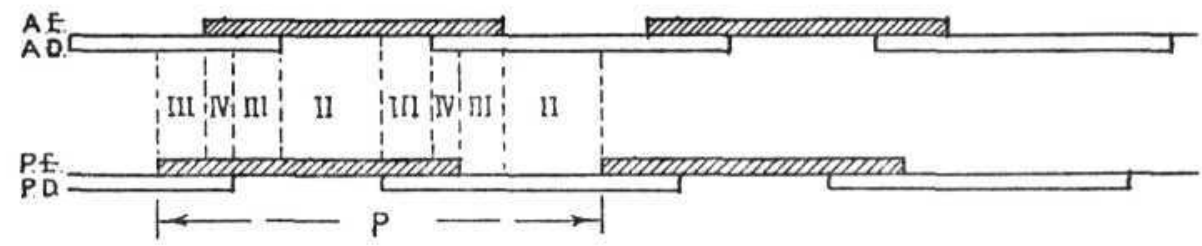

Fig. 17 - Notação da andadura interrompida, segundo Lesbre (F. X. LESBRE)

em vez de duas batidas, ouvem-se quatro, aproximadas duas a duas, e em vez de quatro periodos de apoio, observam-se oito, pois que, entre cada apoio lateral, ha um apoio quadrupedal e dois tripedais.

Nesta modalidade de andadura, o aumento de estabilidade deveria determinar diminuição de velocidade; contudo, diz LESBRE que a velocidade é aumentada em consequencia da maior amplitude do

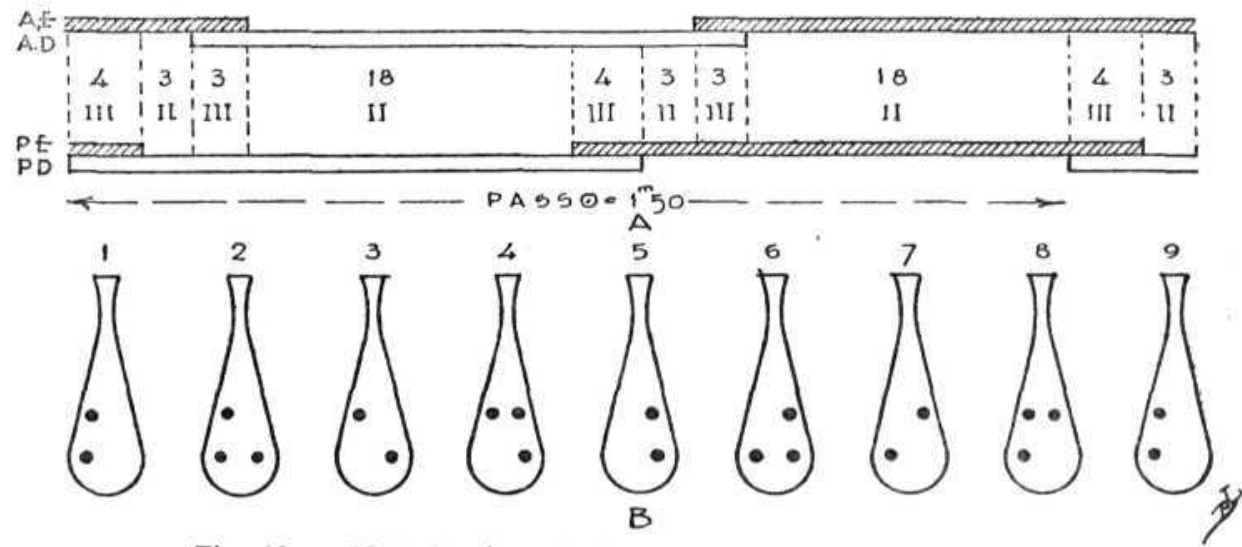

Fig. 18 - Notação da andadura interrompida de animal novo A - processo de Marey

B - processo de Smith (Original)

passo, pois é sabido que a velocidade de um andamento qualquer está mais em relação com o comprimento do passo que com sua frequencia.

Do confronto do que dizem os autores com nossas observações pessoais, resulta que ha diferentes tipos de andadura interrompida. Assim é que obtivemos duas modalidades desta variedade de anda- 
mento: I) a primeira, que coincide com a andadura interrompida descríta por Goubaux e BARRIER, foi observada em um animal novo (Fig. 18-A e B).

Pela notação A, verifica-se: 1) ha evidente predominancia dos apoios laterais, que correspondem a pouco mais da metade da duração do passo; 2) os periodos de apoio de cada membro são sensivelmente iguais; 3 ) os membros posteriores precedem os anteriores correspondentes, tanto no "pôr» como no «levantar», de modo que os periodos de apoio lateral ficam separados por dois apoios tripedais (um anterior e outro posterior) e um diagonal, como melhor se evidencía pela notação $\mathrm{B}$;

II) a segunda (Fig. 19-A e B, Est. I), é a notação da andadura de uma égua Mangalarga.

Embora a fotografia, que encíma a estampa, extraída do film, dê a impressão de uma andadura tipica, a sequencia do andamento, representada pelo grafico, mostra tratar-se de uma modalidade de andadura interrompida não mencionada pelos autores compulsados. Parece ser, pelo menos quanto à sucessão dos apoios, uma variedade do andamento "marcha» que mais se aproxima da andadura e muito conhecida pelos nossos criadores.

Observa-se em A: 1) ha, do mesmo modo que na modalidade anterior, predominancia dos apoios laterais; 2) os periodos de apoio dos membros posteriores são mais longos que os dos anteriores; 3 ) os membros posteriores se "põem» e se «levantam» antes dos anteriores correspondentes. Em consequencia dêste fáto e da maior duração do apoio dos membros anteriores, verifica-se um curto periodo de apoio monopedal posterior. Entre os dois apoios laterais, ha um periodo de sustentação tripedal, um bipedal diagonal e um monopedal, mais claramente evidenciados em B. Êste ultimo, de diminuta duração, correspondendo à báse de sustentação tripedal posterior da andadura representada na figura 18 , constitue a principal diferenciação entre as duas modalidades.

b) Andadura saltada - A instabilidade da andadura torna-se maior e, consequentemente a velocidade, quando, entre os periodos de apoio lateral, se intercala um periodo de suspensão. Esta modalidade constitue a andadura saltada, denominada "pacing» ou «racking» pelos inglêses. Os deslocamentos verticais do centro de gravidade são mais acentuados, sendo, portanto, mais ásperas as reações.

Pista - A pista da andadura é sempre dupla. Os membros posteriores fazem seu apoio adeante das pégádas dos anteriores cor- 
respondentes. O animal, portanto, se ultra-cobre, como se verifica na figura 16.

$\mathrm{Na}$ andadura saltada, havendo periodos de projeção, as pégádas dos membros posteriores são situadas muito mais adeante que as dos anteriores do mesmo lado.

Comprimento do passo e velocidade - Segundo LENOBLE DU TEIL, o comprimento do passo em andadura, de um cavalo de 1,60 metros, é de 1,80 metros, sendo sua velocidade de 8.640 metros por hora.

A simples estatura dos animais não permite comparar a dimensão do passo e velocidade por nós obtidas, com a citação dos AA..

$O$ primeiro animal que nos serviu de báse para o estudo dêste andamento, sendo ainda pôtro, revelou um passo de 1,50 metros, executado em 56/64 de segundo. Sua velocidade horaria teorica seria, portanto de 6.171 metros. Já no caso da égua Mangalarga, cujo passo medía 1,70 metros, efetuado em 50/64 de segundo, a velocidade seria, teoricamente, de $7.833,60$ metros por hora.

A velocidade horaria dos andamentos rapidos é sempre considerada sob o ponto de vista teorico, porquanto nem um animal mantem o mesmo andamento e a mesma velocidade, durante uma hora de marcha.

Se no ultimo animal, considerarmos o comprimento do passo e a duração correspondente a cada periodo de apoio, obteremos, teoricamente, em uma hora de marcha, os dados do seguinte quadro:

\begin{tabular}{c||c|c|c}
\hline & $\begin{array}{c}\text { Duração } \\
\text { dos apoios } \\
\text { em cada } \\
\text { passo }\end{array}$ & $\begin{array}{c}\text { Duração dos } \\
\text { apoios em } \\
\text { uma hora de } \\
\text { marcha }\end{array}$ & $\begin{array}{c}\text { Deslocamento } \\
\text { do corpo, sôbre } \\
\text { o apoio, em uma } \\
\text { hora de marcha }\end{array}$ \\
\hline \hline Lateral esquerdo . . . & $\frac{16^{\prime \prime}}{64}$ & $19^{\prime} 12^{\prime \prime}$ & $2.506,752 \mathrm{~ms}$. \\
Trip. ant. esquerdo . . & $\frac{4^{\prime \prime}}{64}$ & $4^{\prime} 48^{\prime \prime}$ & $626,688 \mathrm{~ms}$. \\
Diagonal esquerdo. . . & $\frac{4^{\prime \prime}}{64}$ & $4^{\prime} 48^{\prime \prime}$ & $626,688 \mathrm{~ms}$. \\
Monop. post. direito . . & $\frac{1^{\prime \prime}}{64}$ & $1^{\prime} 12^{\prime \prime}$ & $156,672 \mathrm{~ms}$. \\
Lateral direito . . . . & $\frac{16^{\prime \prime}}{64}$ & $19^{\prime} 12^{\prime \prime}$ & $2.506,752 \mathrm{~ms}$. \\
Trip. ant. direito . . . & $\frac{4^{\prime \prime}}{64}$ & $4^{\prime} 48^{\prime \prime}$ & $626,688 \mathrm{~ms}$. \\
Diagonal direito . . . & $\frac{4^{\prime \prime}}{64}$ & $4^{\prime} 48^{\prime \prime}$ & $626,688 \mathrm{~ms}$. \\
Monop. post. esquerdo . & $\frac{1^{\prime \prime}}{64}$ & $1^{\prime} 12^{\prime \prime}$ & $156,672 \mathrm{~ms}$. \\
\hline Soma . . . . . & $\frac{50^{\prime \prime}}{64}$ & $60^{\prime}$ & $7.833,600 \mathrm{~ms}$. \\
\hline
\end{tabular}




\section{b) Trote}

Definição - O trote é um andamento natural, simetrico, a dois tempos, normalmente saltado, no qual os membros diagonais se revezam no apoio e na suspensão.

Notação - Adotando o metodo de MAREY, apresentamos, na figura 20 , a notação de um dos trotes por nós filmado (cavalo uruguaio, de porte médio), por onde se verifica que os apoios diagonais se revezam e são separados por um periodo de suspensão relativamente curto (a quarta parte do periodo de apoio).

Centro de gravidade - $\mathrm{O}$ centro de gravidade sofre deslocamentos laterais menos pronunciados que na andadura, os esforços para evitar a quéda de lado são menores e, por conseguinte, o animal se cansa menos. Em compensação, os deslocamentos verticais, obtidos por um processo analogo ao usado para a andadura, são mais acentuados, determinando reações mais violentas, principalmente na região da cernelha. Para determinar o deslocamento durante o periodo de projeção, foi utilizado um ponto de reparo fixo no terreno. Sendo o corpo impelido para cima e para a frente pela impulsão dos membros e caindo sob ação de seu proprio pêso, o centro de gravidade descreve, em cada passo, duas curvas, cujos periodos de descenção são mais acentuados que os de ascenção.

A figura 21 mostra-nos a pista deixada por um animal de 1,63 ms. de altura, em trote normal, cujo passo medía 2,40 metros.

Analogamente à figura 16 , os traços cheios representam as báses de apoio dos bipedes diagonais associados em cada passo; os traços finos, a projeção do deslocamento horizontal do centro de gravidade, que descreve u'a linha semelhante à da andadura, porém menos aproximada dos limites laterais, ligando, mais ou menos, os terços anteriores das sucessivas báses de sustentação; as curvas, a

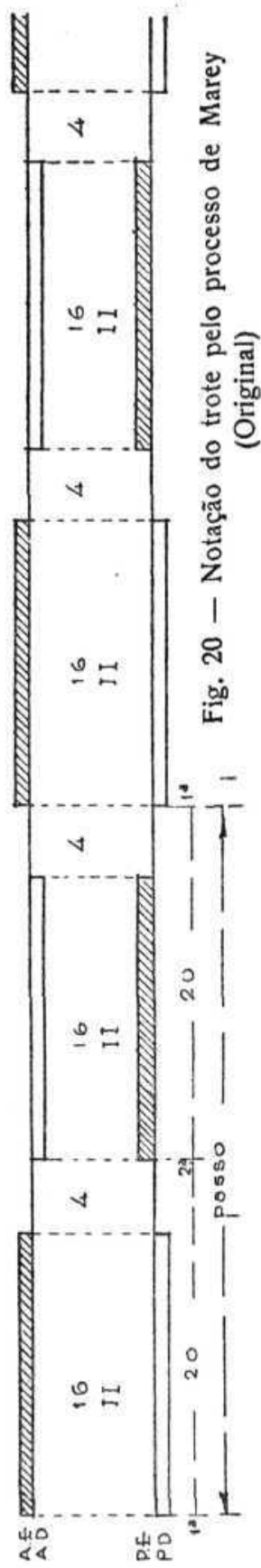
projeção do deslocamento vertical. Estas curvas, em numero de duas para cada passo, não apresentam angulos de inflexão em seu ponto 
mais baixo, nem um periodo de descenção tão acentuado, como mostram as figuras dos tratados.

Marey, citado por Marchi, diz: "Vê-se que o momento em que o corpo do animal está no ponto mais baixo de sua oscilação vertical coincide com aquêle em que os pés não tocam o sólo. A fáse de suspensão não é devida à projeção do corpo no ar, mas à flexão dos quatro membros, durante um certo momento. A altura maxima alcançada pelo corpo corresponde, ao contrário, ao fim do apoio dos membros".

LEONEBle DU TEIL concorda com MAREY no que diz respeito à projeção do corpo do animal, mas não é da mesma opinião quanto ao deslocamento vertical do centro de gravidade, pois considera o ponto mais alto correspondendo ao periodo de suspensão, e o mais baixo,

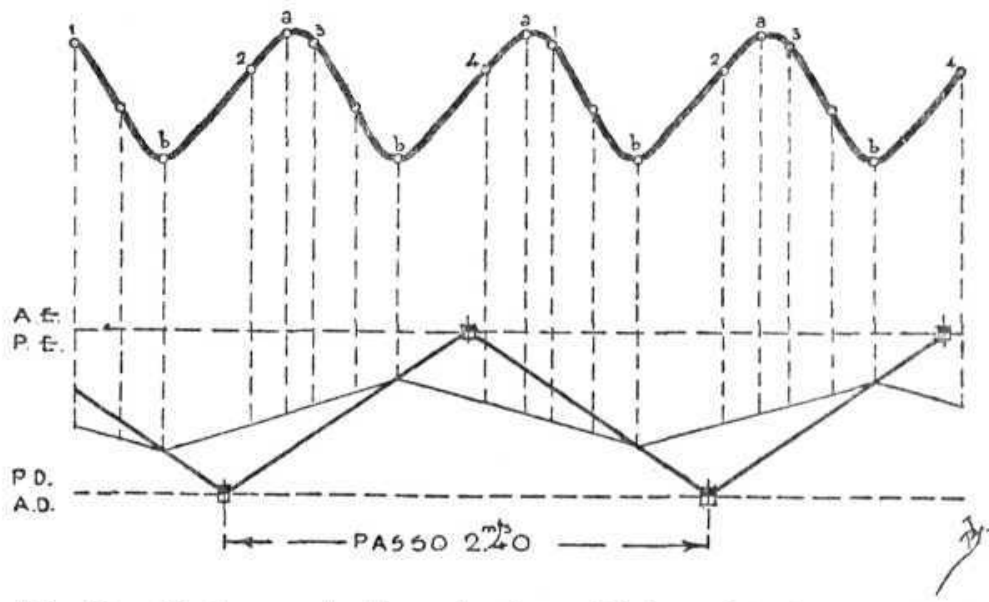

Fig. 21 - Deslocamento do centro de gravidade e pista de um animal em trote (Original)

ao de apoio. Entretanto, para LeNOBLE DU TEIL, a altura maxima dêsse deslocamento é sempre inferior à altura da cernelha.

Pelo minucioso estudo feito com auxilio dos films, supômos que o corpo do animal seja impelido para deante e para cima pela impulsão dos membros; que o centro de gravidade, em seu deslocamento vertical, descreva, como vimos anteriormente, uma curva cuja altura maxima corresponde aos periodos de projeção, enquanto que a minima, aproximadamente ao meio dos periodos de apoio.

Pista - A pista é simples no trote normal, pois ha superposição das pégádas e o animal se cobre (Fig. 21). Será dupla em outras modalidades que serão tratadas posteriormente. 
Modalidade do trote - As modalidades do trote são diversas segundo o ponto de vista em que o andamento é considerado. Assim temos:

1) Variedades de velocidade e de pista.

2) Variedades segundo o sincronismo das batidas.

3) Variedades segundo a desigualdade dos apoios.

1) Variedades de velocidade e de pista - De acôrdo com a velocidade e as impressões deixadas no sólo pelos pés, o trote pode ser curto, normal ou alongado.

a) Trote curto - Quando, em virtude do menor comprimento do passo, a velocidade é reduzida e as pégádas dos membros posteriores ficam atrás das dos anteriores correspondentes, o trote é chamado curto. Os periodos de projeção são muito pequenos e podem mesmo desaparecer, tornando o andamento marchado. Nêste caso, ha um periodo de apoio quadrupedal entre os apoios diagonais (Fig. 22), o que aumenta a estabilidade e, consequentemente, diminue a velocidade.

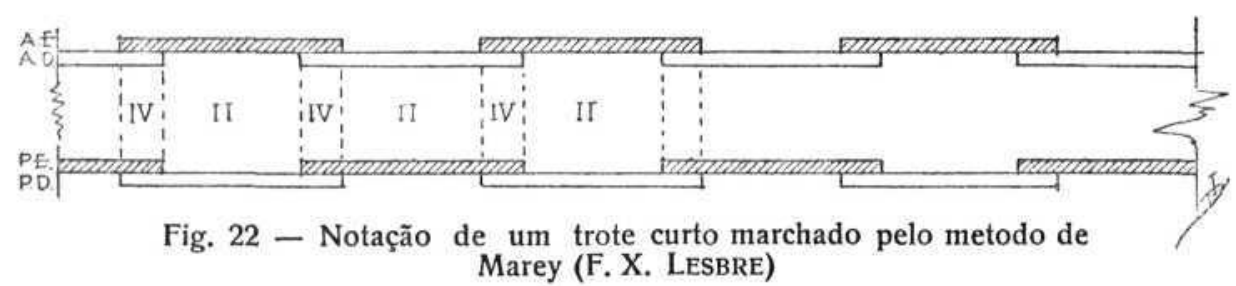

Durante êste periodo, um bipede está em «levantar» e o outro em "pôr», correspondendo à fáse de projeção, e o deslocamento vertical do centro de gravidade ocupa uma posição mais elevada.

b) Trote normal - E' aquele no qual as pégádas dos membros posteriores se sobrepõem às dos anteriores correspondentes, isto é, o animal se cobre. A velocidade é aumentada relativamente ao trote curto, porque o passo é maior. A estabilidade torna-se menor em virtude da supressão do apoio quadrupedal, que é substituido pela fáse de projeção. O deslocamento do centro de gravidade é o representado na figura 21 .

c) Trote alongado - Quando os periodos de suspensão se tornam mais longos e a passada maior, aumentando assim a velocidade, o trote será chamado alongado. Nêste caso o animal se ultra-cobre, isto é, as pégádas dos membros posteriores ficam adeante das dos anteriores correspondentes. O centro de gravidade sofre deslocamentos semelhantes ao das variedades já descritas. 
2) Variedades segundo o sincronismo das batidas - As batidas dos membros diagonais podem ser associadas ou dissociadas. No primeiro caso, o trote é chamado a dois tempos e ouvem-se duas batidas em cada passo (trote curto, normal e alongado); no segundo, o trote

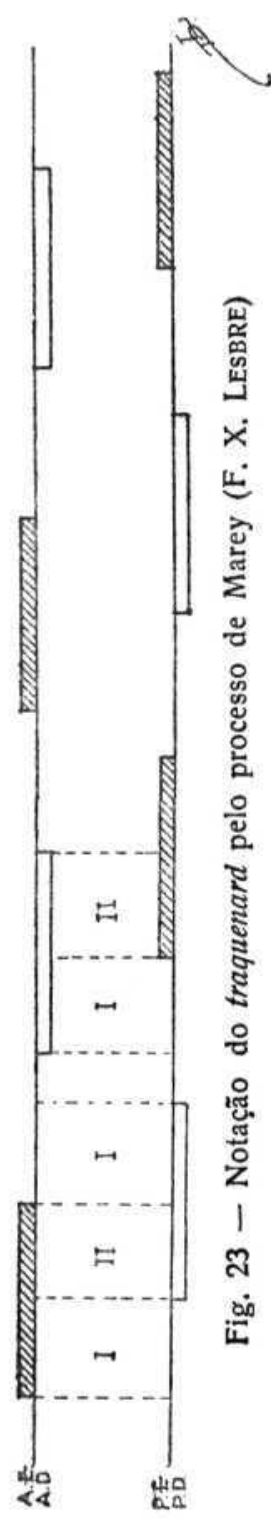
é a quatro tempos e ouvem-se, em cada passo, quatro batidas, aproximadas duas a duas. Os membros posteriores podem "pôr-se» antes ou depois dos anteriores opostos em diagonal. O trote a quatro tempos recebe ainda os nomes de trote desunido, interrompido, descosido, traquenard, trote de corrida ou flying-trot. Estas denominações são sinónimas sob o ponto de vista da dissociação das batidas, mas são empregadas diferentemente, segundo as condições em que a dissociação se manifesta (Goubaux e Barrier). Não havendo entre os diferentes AA., uma certa uniformidade na aplicação dêsses termos, somos levados a interpretá-los segundo melhor nos parece. Assim, reservamos as denominações de trote desunido, interrompido e descosido às dissociações das batidas, quaisquer que sejam, independentemente das báses de apoio e da velocidade do andamento. Chamamos traquenard às dissociações que se observam em animais caminhando em trote curto, sempre que se fórça sua velocidade. A antecipação do apoio tanto pode ser feita pelos membros posteriores como pelos anteriores. No primeiro caso, dizse que o traquenard é sobre as ancas; no segundo, sobre as espáduas (Fig. 23).

Em ambos os casos, antes e depois do apoio bipedal diagonal, ha um periodo de apoio monopedal, o que torna maior a instabilidade e, consequentemente, a velocidade. As reações são mais suaves que no trote ordinário. Os periodos de projeção podem diminuir ou mesmo desaparecer, tornando o andamento marchado (Fig. 24).

Nêste caso, o equilibrio será mais estavel e a velocidade menor.

Alguns autores, entre êles Zwaenepoel, Magliano, etc., consideram esta modalidade como defeituosa.

Dá-se a denominação de trote de corrida ou flying-trot, sempre que a dissociação se verifica no trote alongado, quando a velocidade já é consideravel. Os membros anteriores se apoiam e se elevam an- 
tes que os posteriores que thes são opostos em diagonal, havendo tambem dois periodos de apoio monopedal, um posterior e outro anterior (Fig. 25), antes e depois de cada periodo de suspensão. Os deslocamentos laterais do centro de gravidade são acentuados em consequencia do apoio monopedal, que determina tambem aumento de instabilidade e de velocidade. Segundo De Gasté, esta modalidade de trote é artificial. Houve mesmo um hipólogo, EpHrem Howel, que propôs a

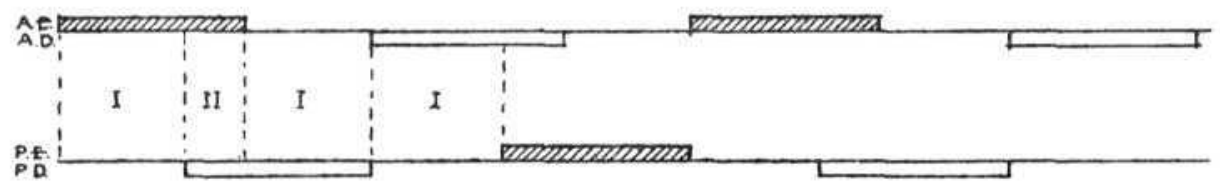

Fig. 24 - Notação do traquenard marchado pelo processo de Marey (F. X. LESBRE)

eliminação do trote de corrida dos hipódromos, visto como a violencia das reações suportadas pelos membros acarreta a ruina das articulações, inutilizando completamente o animal.

3) Variedades segundo a desigualdade dos apoios - De acôrdo com o Coronel Gossart, a duração dos apoios dos membros posteriores não é sempre igual à dos anteriores, confórme êle comprova por meio de cronofotografias. Não fizemos observações referentes a êsse assunto, embora a opinião acima nos pareça acertada.
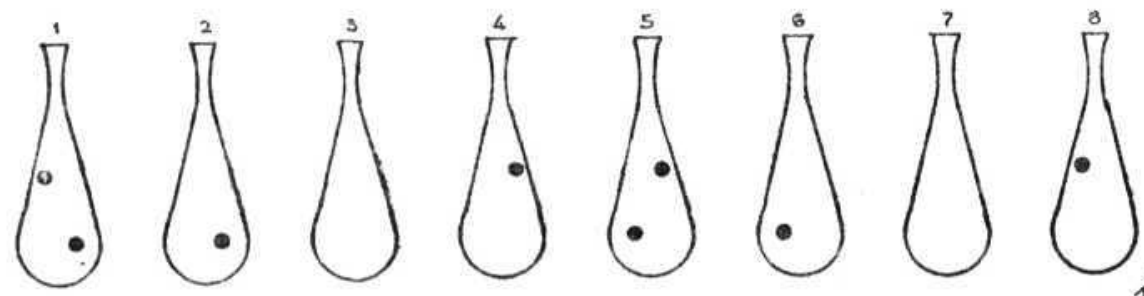

Fig. 25 - Notação do trote de corrida pelo metodo de Smith (F. SMIrH)

Comprimento do passo e velocidade - E' extremamente dificil precisar o comprimento do passo em um animal a trote, porquanto o talhe, a amplitude da base de sustentação, o comprimento dos óssos, a abertura dos angulos articulares, etc., fazem-no variar sobremodo. Comtudo, Lenoble Du Teil estabelece a média de 2,40 metros para um cavalo de talhe igual a 1,60 metros, o que coincide com os dados de Goubaux e Barrier. 
A velocidade está em relação com a modalidade do trote. Do mesmo modo que o comprimento do passo, varía em razão diréta com a extensão do periodo de projeção. Para um trote normal, a velocidade média é de 240 metros por minuto.

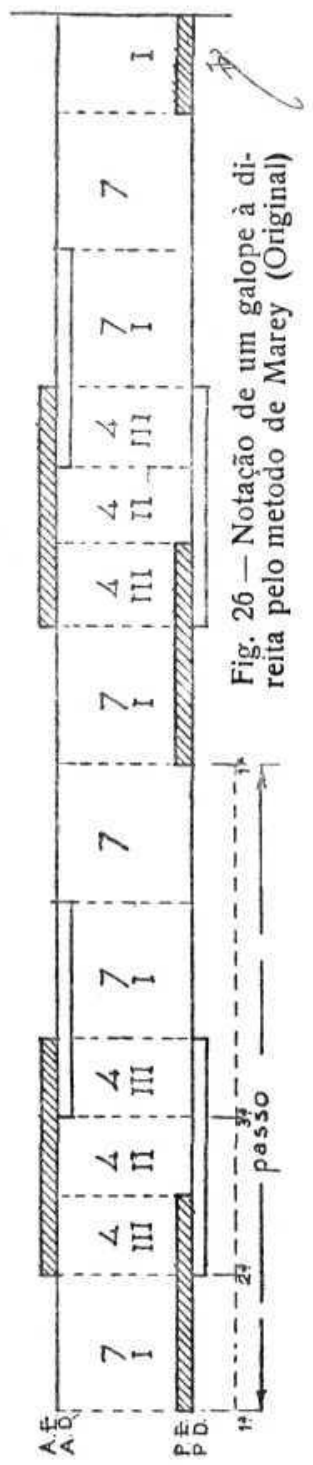

Levando em consideração esta velocidade e a duração dos periodos de apoio e de suspensão, obteremos, em uma hora de marcha, os dados constantes do seguinte quadro:

\begin{tabular}{c||c|c|c}
\hline \hline & $\begin{array}{c}\text { Duração } \\
\text { dos apoios } \\
\text { em cada } \\
\text { passo }\end{array}$ & $\begin{array}{c}\text { Duração dos } \\
\text { apoios em } \\
\text { uma hora de } \\
\text { marcha }\end{array}$ & $\begin{array}{c}\text { Deslocamento } \\
\text { do corpo, sôbre } \\
\text { o apoio, em uma } \\
\text { hora de marcha }\end{array}$ \\
\hline \hline Bípede diagonal esq. & $\frac{16^{\prime \prime}}{64}$ & $26^{\prime} 40^{\prime \prime}$ & $6.400 \mathrm{~ms}$. \\
Suspensão . . . . & $\frac{4^{\prime \prime}}{64}$ & $6^{\prime} 40^{\prime \prime}$ & $1.600 \mathrm{~ms}$. \\
Bípepe diagonal dir. & $\frac{16^{\prime \prime}}{64}$ & $26^{\prime} 40^{\prime \prime}$ & $6.400 \mathrm{~ms}$. \\
\hline Soma. . . & $\frac{36^{\prime \prime}}{64}$ & $60^{\prime}$ & $14.400 \mathrm{~ms}$. \\
\hline
\end{tabular}

Defeituosidade do trote - «Aubin». O aubin é uma defeituosidade que se observa em animais velhos ou exgotados e que se caracteriza pelo galopar do bípede anterior ou posterior, enquanto o outro continúa em trote. Diz-se que é de frente ou de trás, de acôrdo com o bípede que se movimenta em galope. O aubin de frente é o mais comum. Chaves de Lemos dá a esta defeituosidade a denominação de trote semi-desunido, chamando «travadinho» o trote semi-desunido de trás.

\section{c) Galope}

Definição - O galope é um andamento natural, saltado, diagonal, asimetrico, no qual as batidas dos membros posteriores antecipam as dos anteriores correspondentes. Será à direita ou à esquerda, de acôrdo com o último membro anterior que deixa o sólo antes do periodo de suspensão.

Notação - Na figura 26, apresentamos, pelo metodo de MAREY, a notação de um galope à direita, obtida, por filmagem. 
Após cada periodo de suspensão, as batidas se fazem, sucessivamente, por um membro posterior, um bípede diagonal associado e um membro anterior. Assim, se em seguida ao periodo de projeção, o apoio se fizer pelo membro posterior esquerdo, como mostra a figura, seguir-se-ão o bípede diagonal esquerdo e depois o membro anterior direito.

Pela notação de SMith (Fig. 27), observamos que a báse de sustentação é, a principio, unipedal posterior (2), torna-se em seguida, tripedal anterior (3), bipedal diagonal (4), tripedal posterior (5) e monopedal (6), seguindo-se o periodo de projeção (7).
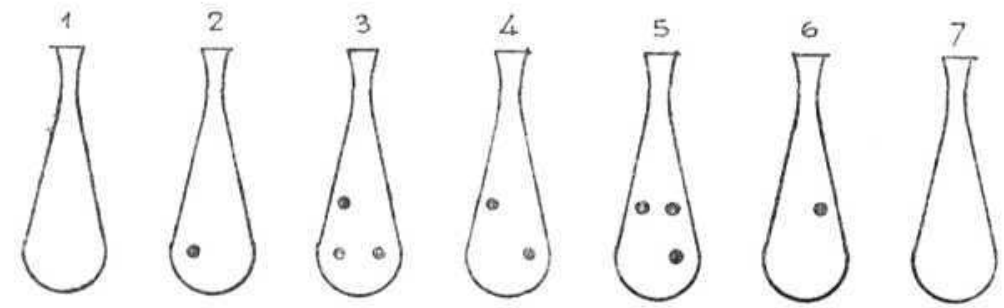

Fig. 27 - Notação de um galope à direita pelo metodo de Smith (Original)

Centro de gravidade - Os apoios monopedais, no inicio e no fim de cada passo, revelam grande instabilidade de equilibrio nêsses momentos. O deslocamento horizontal do centro de gravidade, pouco pronunciado, descreve u'a linha quebrada, dirigindo-se para o lado em que o animal galópa, durante os periodos de apoio, e para o lado oposto durante os periodos de projeção. $\mathrm{O}$ angulo formado por essas linhas será tanto maior quanto mais longos fôrem êstes ultimos periodos. Imaginando um animal em galope à esquerda, o centro de gravidade se desloca da direita para a esquerda, dêsde o primeiro apoio posterior até o ultimo anterior, e da esquerda para a direita, durante o periodo de projeção (Fig. 28). Nesta figura, que é a representação de um galope curto, as pégádas dos membros diagonais associados figuram reunidas por um traço cheio.

Quanto ao deslocamento vertical, o centro de gravidade descreve curvas semelhantes às do trote, sendo, porém, maiores e mais suaves, porque no trote ha dois periodos de projeção em cada passo e, consequentemente, duas curvas, enquanto que no galope só ha um e, portanto, uma só curva.

O ponto mais alto do deslocamento vertical acha-se situado proximo do fim do periodo de projeção, enquanto que o mais baixo se verifica dentro do periodo de apoio do bípede diagonal associado. 


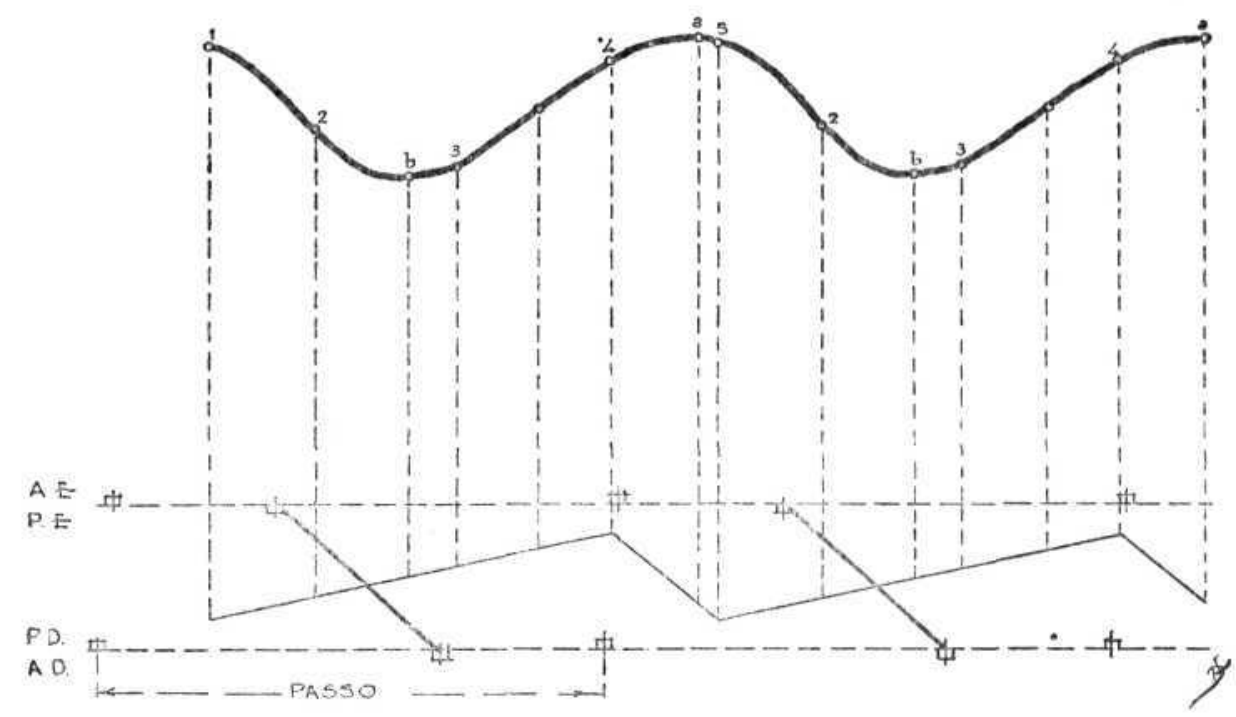

Fig. 28 - Deslocamento do centro de gravidade e pista de um animal em galope (Original)

Modalidade de galope - Existem duas modalidades de galope: o de três e o de quatro tempos.

a) Galope a três tempos - Considerado galope normal, foi o que tomámos por báse para a descrição feita anteriormente.

No galope a três tempos, existe uma variedade denominada pequeno galope marchado, que é observada quando o membro posterior, que inicia o passo, se "põe» antes do «levantar» do anterior oposto. $\mathrm{O}$ apoio do bípede diagonal associado tem início, mais ou menos, no primeiro terço do apoio do membro posterior que começa o passo. A báse de sustentação é a principio bipedal, em virtude da permanencia em apoio do membro anterior que termina o passo precedente, sendo, em seguida, constituida por um, três, quatro, três e um membro, sucessivamente (Fig. 29).

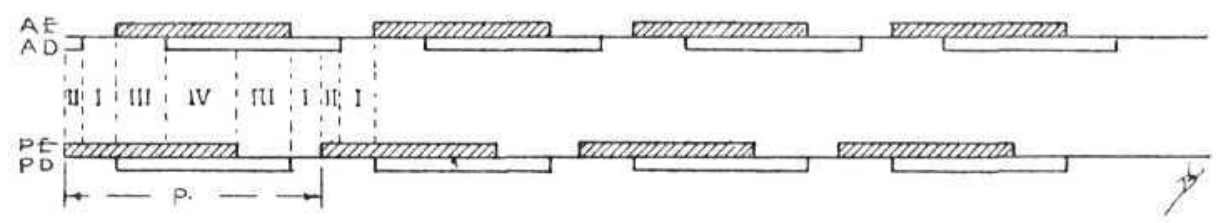

Fig. 29 - Notação do pequeno galope marchado pelo metodo de Marey (F. X. LESBRE) 
A estabilidade do equilíbrio será maior, porque o passo se inicía em apoio bipedal; ha um apoio quadrupedal; é suprimido o periodo de projeção e o andamento é mais lento. O centro de gravidade, em seus deslocamentos horizontais, descreve u'a linha quebrada, como no galope a três tempos, porém, os angulos são mais fechados pelo fáto de não haver periodos de projeção.

b) Galope a quatro tempos - E' aquele em que o bípede diagonal se dissocía de modo que se ouvem quatro batidas em vez de três. Este andamento pode ser lento ou rapido. A velocidade aumenta à medida que diminuem os periodos compreendidos entre os apoios dos membros posteriores ou dos anteriores, porque esta diminuição favorece à ação conjunta dos membros similares. Em uma notação reconhece-se a maior ou menor velocidade desta modalidade de galope, pelo maior ou menor afastamento entre os apoios do segundo e terceiro membros. De acôrdo com a velocidade, distinguem-se, no galope a quatro tempos, o pequeno galope e o galope de corrida. O primeiro pode ser sôbre as ancas ou sôbre as espáduas. Quando os apoios dos membros posteriores precedem os dos anteriores, diz-se que o animal galópa sôbre as ancas. No galope à direita, por exemplo, os apoios se fazem na seguinte ordem: posterior esquerdo, posterior direito, anterior esquerdo e anterior direito (Fig. 30).

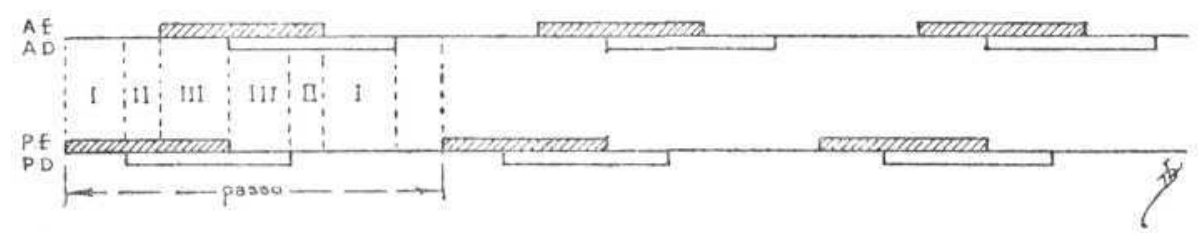

Fig. 30 - Notação do pequeno galope a quatro tempos sôbre as ancas pelo processo de Marey (F. X. LesBre)

Esta modalidade, caracterizada pela grande elevação do trem anterior, é mais um andamento de alta escola.

Quando, depois do primeiro apoio posterior, se «põe» um membro anterior, antes que o posterior oposto em diagonal, diz-se que o galope é sôbre as espáduas. Considerando ainda o galope à direita, a ordem dos apoios será a seguinte: posterior esquerdo, anterior esquerdo, posterior direito e anterior direito (Fig. 31).

No pequeno galope sôbre as espáduas, o periodo de suspensão é muito reduzido, podendo mesmo desaparecer, dando lugar ao pequeno galope marchado a quatro tempos. 
No pequeno galope sobre as ancas, como vemos na figura 30 , a báse de sustentação é, sucessivamente, monopedal posterior, bipedal posterior, tripedal anterior, tripedal posterior, bipedal anterior e monopedal anterior. O equilíbrio é mais instavel no começo e no fim de cada passo, do mesmo modo que no galope a três tempos. O mesmo se verifica no pequeno galope sôbre as espáduas, porém nêste, o equilíbrio é mais estavel porque existe um periodo de apoio quadrupedal e tambem porque a suspensão é reduzida ou mesmo nula. A báse de sustentação é, sucessivamente, monopedal posterior, bipedal lateral, tripedal anterior, quadrupedal, tripedal posterior, bipedal lateral e monopedal anterior (Fig. 31).

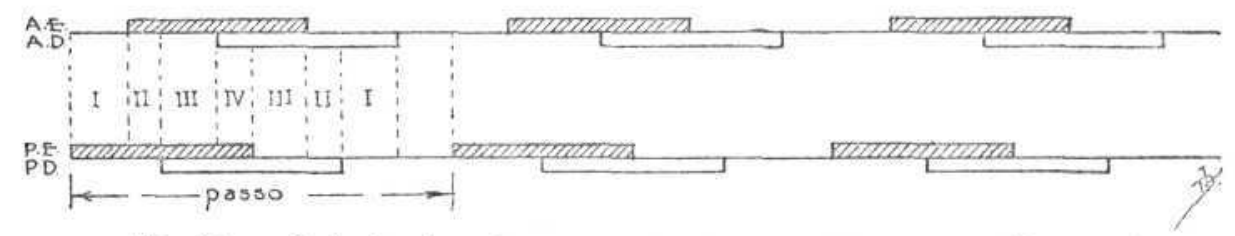

Fig. 31 - Notação do galope a quatro tempos sôbre as espáduas pelo processo de Marey (F. X. LesBre)

O galope de corrida foi tido, por muito tempo, como um andamento particular, no qual o cavalo saltava do bípede posterior sôbre o anterior. Assim é que as pinturas e esculturas antigas representam o cavalo a galope em atitudes que não correspondem à realidade, para êstes animais, pois, conforme diz P. MAGNE DE LA Croix, aquelas atitudes caracterizam o galope terciário empregado pelos coelhos, lebres, gatos da ilha de Man, etc.. Para Richard du Cantal, Lecoq, Colin, etc., era um galope a três tempos, muitissimo alongado, no qual as três batidas de cada passo eram separadas pelo periodo de projeção, feito muito próximo da terra. MAREY considerava-o como um andamento a quatro tempos, no qual as batidas dos membros posteriores, bem como as dos anteriores, eram tão aproximadas que o ouvido percebia sómente duas batidas em cada passo. Para êste autor, o período de projeção estava colocado entre os apoios posterior e anterior contrariamente ao que demonstrou LENOBLE DU TEIL, isto é, que o período de projeção do galope de corrida, como nos outros galopes, está situado entre dois passos sucessivos.

A figura 32, que é a reprodução de um dos galopes por nós filmados, evidencía claramente:

a) que o galope de corrida é um andamento saltado, a quatro tempos;

b) que as batidas dos membros posteriores são mais aproximadas que as dos anteriores; 
c) que a fáse de projeção, mais curta do que se supunha, se coloca depois do último apoio dos membros anteriores;

d) que as báses de sustentação se fazem, alternativamente, sôbre um e dois membros;

e) que as báses de apoio têm duração diferente, sendo mais longa a do anterior sôbre o qual o animal galópa.

O equilíbrio será muito instavel em consequencia da exiguidade lateral da báse de sustentação, pois os membros se apoiam quasi que sôbre uma mesma linha. As oscilações laterais do centro de gravidade são, portanto, mínimas, e as verticais são tambem pouco pronunciadas, porque a impulsão é feita mais para deante do que para o alto.

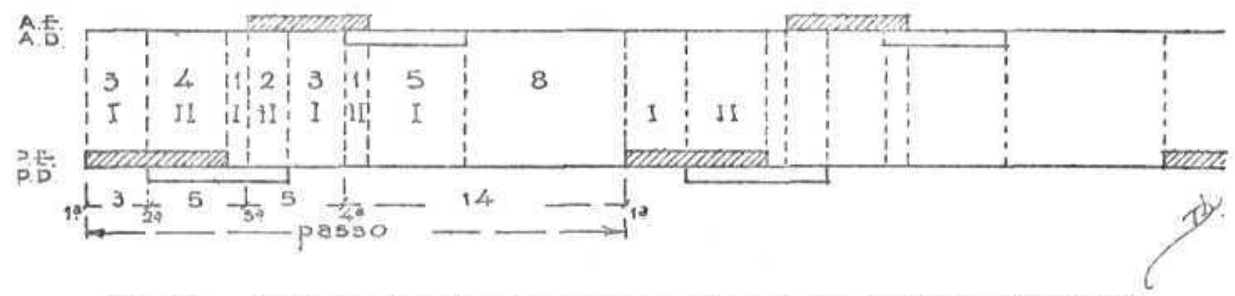

Fig. 32 - Notação do galope de corrida pelo processo de Marey (Original)

Pista - Na pista de um animal a galope, as pégádas são grupadas quatro a quatro. Conforme se verifica na figura 28 , a impressão de um membro lateral, do lado em que o animal galópa, fica sempre na frente da de seu congênere, donde se depreende que o galope é um andamento asimetrico.

No galope normal e no alongado, a pégáda do membro que inicia o passo fica do lado e adeante da impressão deixada pelo membro que o termina. Êste adeantamento diminue proporcionalmente com a velocidade, fazendo-se a primeira pégáda em posição lateral ou posterior à última. No galope muito curto, feito quasi sôbre o lugar, as impressões dos pés posteriores se fazem sôbre as dos anteriores do mesmo lado ou mesmo atrás delas, isto é, o animal se cobre ou se descobre.

Comprimento do passo e velocidade - Do mesmo modo que nos demais andamentos, o comprimento do passo e a velocidade, no galope, são muito variaveis. Em média, para o galope normal, o comprimento do passo é de 3,60 metros para um cavalo de 1,60 metros de talhe (RAABE) e a velocidade, de 300 metros por minuto. Para o galope de corrida, o passo póde variar de 5 a 7 metros e a velocidade, de 14 a 15 metros por segundo.

No galope representado pela figura 26 , a duração de cada báse de apoio foi, respetivamente, de $7,4,4,4,7$ e 7 sessenta e quatro ávos 


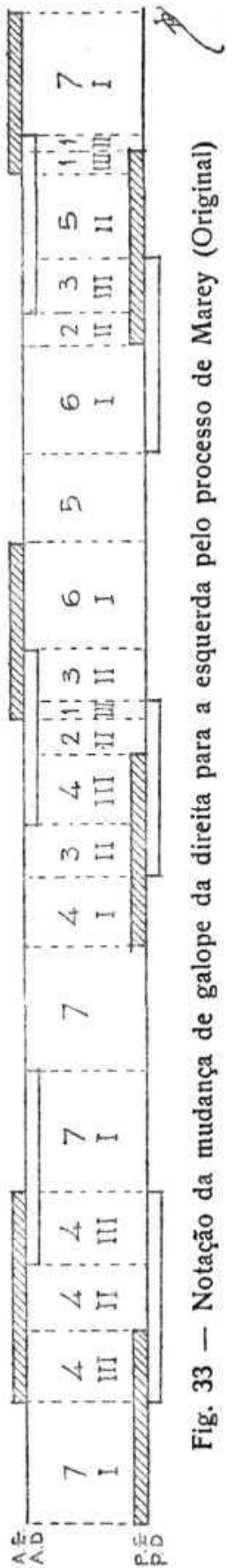

de segundo. O quadro abaixo mostra o tempo de cada apoio e a distancia percorrida sôbre cada um dêles, após uma hora de galope regular, com a velocidade de 300 metros por minuto.

\begin{tabular}{|c|c|c|c|c|}
\hline & & $\begin{array}{c}\text { Duraçāo } \\
\text { dos apoios } \\
\text { em cada } \\
\text { passo }\end{array}$ & $\begin{array}{l}\text { Duração dos } \\
\text { apoios em } \\
\text { uma hora de } \\
\text { marcha }\end{array}$ & $\begin{array}{l}\text { Deslocamento do } \\
\text { corpo, sôbre cada } \\
\text { apoio, em uma } \\
\text { hora de marcha }\end{array}$ \\
\hline Monop. post. esquerc & & $\frac{7^{\prime \prime}}{64}$ & $12^{\prime} 43^{\prime \prime} \frac{7}{11}$ & $3.818 \mathrm{~ms}$. \\
\hline Trip. ant. esquerdo & ·. $\cdot$ & $\frac{4^{\prime \prime}}{64}$ & $7^{\prime} 16^{\prime \prime} \frac{4}{11}$ & $2.181 \mathrm{~ms}$. \\
\hline Bip. diag. esquerdo & . . & $\frac{4^{\prime \prime}}{64}$ & $7 \cdot 16^{\prime \prime} \frac{4}{11}$ & $2.181 \mathrm{~ms}$. \\
\hline Trip. post. direito . & . . & $\frac{4^{\prime \prime}}{64}$ & $7^{\prime} 16^{\prime \prime} \frac{4}{11}$ & $2.181 \mathrm{~ms}$. \\
\hline Monop. ant. direito & . . & ${\frac{7^{\prime \prime}}{64}}^{\prime \prime}$ & $12^{\prime} 43^{\prime \prime} \frac{7}{11}$ & $3.818 \mathrm{~ms}$. \\
\hline Suspensão. . . . & . . & $\frac{7^{\prime \prime}}{64}$ & $12^{\prime} 43^{\prime \prime} \frac{7}{11}$ & $3.818 \mathrm{~ms}$. \\
\hline Soma . . . & · . & $\frac{33^{\prime \prime}}{64}$ & $59^{\prime} 58^{\prime \prime}$ & $17.997 \mathrm{~ms}$. \\
\hline
\end{tabular}

Mudança de galope - No decurso de um galope prolongado, o cavalo muda o lado em que galópa afim de distribuir igualmente o trabalho pelos membros. $\mathrm{Na}$ transição representada pela figura 33 , a mudança da direita para a esquerda se efetuou pelo adeantamento dos apoios dos membros direitos e retardamento do anterior esquerdo.

Quanto à duração dos apoios, a do membro posterior esquerdo ficou inalterada, enquanto que as dos outros membros foi abreviada. As báses de sustentação, que vinham sendo feitas sobre um, três, dois, três e um membro, passam a ser, no passo de transição sucessivamente, monopedal posterior esquerda, bipedal posterior, tripedal anterior direita, bipedal lateral direita, tripedal posterior direita, bipedal anterior e monopedal anterior esquerda. A transição consistiu, portanto, em um passo de galope desunido, não havendo, porém, associação do bipede lateral. 
Defeituosidades do galope - a) Galope falso - Esta defeituosidade se verifica quando o animal galópa à esquerda ou à direita, em uma curva cujo centro esta situado em direção oposta. O cavalo que galópa em uma curva, inclina o corpo para o lado interno desta, afim de eximir-se dos efeitos da força centrífuga. No galope normal, para evitar a quéda dêste lado, êle sempre apoia na frente os membros internos. Não se verificando esta condição no galope falso, isto é, sendo apoiados na frente os membros externos, compreende-se que a estabilidade será comprometida, havendo maior probabilidade de quéda para o lado interno.

b) Galope desunido - Quando os membros anteriores galópam à direita, enquanto os posteriores galópam à esquerda ou vice-versa, diz-se que o galope é desunido. Será à direita ou à esquerda, conforme os membros laterais que se põem juntamente em apoio. No galope à direita, por exemplo (Fig. 34-A), a ordem dos apoios será a seguinte: membro posterior esquerdo, bipede lateral direito e membro anterior esquerdo. No galope à esquerda (Fig. 34 -B), a ordem será: membro posterior direito, bipede lateral esquerdo e membro anterior direito.

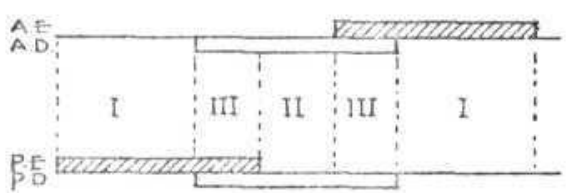

A

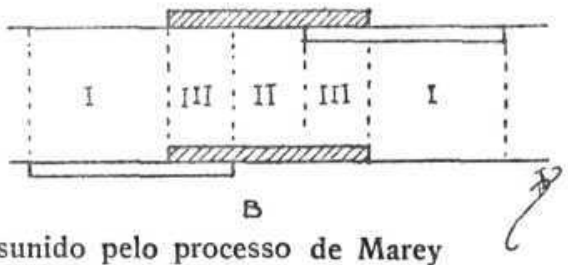

B

Fig. 34 - Notação de um galope desunido pelo processo de Marey A : à direita
B - à esquerda (F, X. Lessire)

No galope desunido, o membro que termina o passo não é, como em todos os galopes, diagonalmente opostos ao que o inicía. Nesta defeituosidade, ha um momento em que o apoio se efetua sôbre um bipede lateral, o que contribue para a diminuição da estabilidade.

Segundo Muybridge, o cavalo executa sempre o galope transverso, isto é, aquele em que a passagem do apoio do segundo para o terceiro membro é feita em diagonal, como mostram as figuras 35-A e B, onde os numeros representam os, apoios sucessivos, enquanto que o cão e outros animais podem executar o galope rotatorio, no qual a passagem referida acima é feita segundo u'a linha lateral (Fig. 35-C). Esta afirmativa está em desacôrdo com a definição de galope desunido dada pelos tratados, se apenas levarmos em consideração a sequencia dos apoios, e tambem não se verifica no passo de transição do galope represendado pela figura 33 , onde a passagem do apoio do segundo para o terceiro membro foi feita segundo u'a linha lateral. 
P. MAGNe DE LA CRoIx preferiu, de acôrdo com a opinião de Bourdelle, dar a estas duas modalidades de galope as denominações de diagonal e lateral.

$\mathrm{Na}$ andadura, trote e passo, os bípedes transversais desempenham a mesma função e nunca atuam conjuntamente, isto é, êles se alternam nos periodos de apoio e de suspensão e os esforços da locomoção se repartem igualmente entre êles. No galope, entretanto, ha um momento em que os membros transversais estão juntos em apoio e, reunindo seus esforços, facilitam sobremodo a propulsão do corpo para a frente.

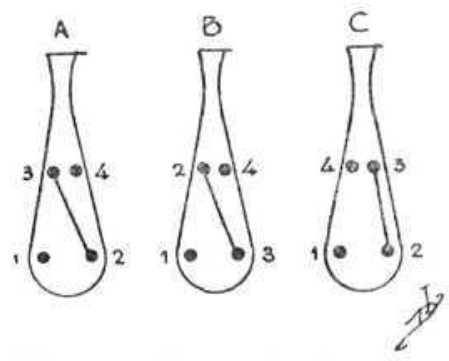

Fig. 35 - Indicação da ordem dos apoios no galope, segundo Muybridge (F. SMITH)

O trabalho executado pelos bipedes diagonais difere em natureza e em quantidade. Enquanto os membros do bipede dissociado têm por função amortecer os choques e sustentar o pêso do corpo, funções estas que cada um executa por sua vez, os do bipede associado são encarregados da propulsão e, como atuam conjuntamente, cansam-se menos que seus congêneres. Estas funções, embora não sejam exclusivas dos membros que acabámos de citar, são as que nêles preponderam.

A. Mangin, em sua tése "Etude sur la fatigue des membres dans le galop - Paris - 1926» é de opinião que os membros associados cansam-se mais que os dissociados, o que está em desacôrdo com a maioria dos AA.. Desconhecemos a tése acima referida, porquanto não nos foi possivel obtê-la.

d) Passo

Definição - O passo é um andamento natural, marchado, simetrico, a quatro tempos, lateral ou diagonal, conforme os membros que estão em apoio nos diversos periodos de um passo completo. Se o membro que se "põe» fôr um anterior, o apoio seguinte será efetuado pelo diagonal oposto; se fôr um posterior, o apoio imediato será feito pelo lateral. 
Notação - Considerando como passo normal aquele em que as batidas são regularmente espaçadas e, portanto, em que ha igualdade entre os apoios laterais e diagonais, a notação será a da figura 36, onde vemos que, se o membro que se "põe» fôr o anterior direito, seguirse-ão, sucessivamente, o posterior esquerdo, o anterior esquerdo e o posterior direito; se fôr o posterior esquerdo, seguir-se-ão o anterior esquerdo, o posterior direito e o anterior direito.

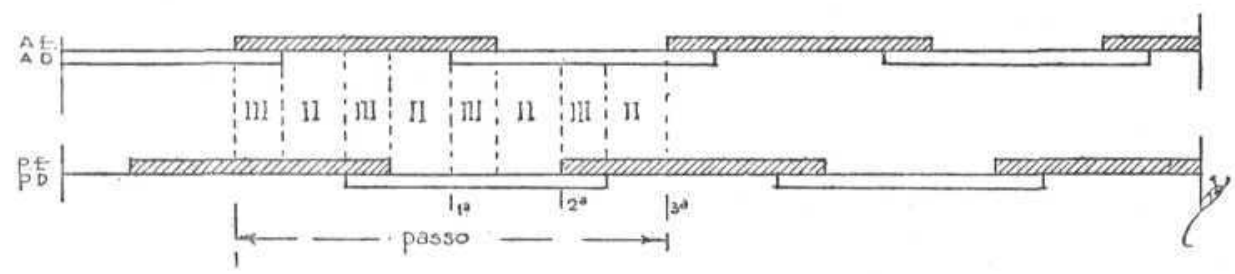

Fig. 36 - Notação do passo normal pelo metodo de Marey (F. X. LESBRE)

Ha divergencias, entre os diferentes AA, no que diz respeito ao membro que inicia o passo, à regularidade das batidas e à báse de sustentação. Enquanto MuYbridge, citado por Smith, diz que «quando um cavalo está em estação, com o pêso do corpo equitativamente distribuido sôbre os membros anteriores e, nestas condições começa o passo, o movimento inicial será, invariavelmente, feito com um membro posterior», estando conforme com o que escreveu Borelli, no seculo XVII, outros AA., entre os quais Percival, Gangee e Hayes asseveram que geralmente o cavalo inicia o passo com um membro anterior. Todos os animais por nós observados, quer em liberdade, quer montados ou atrelados, iniciaram o passo como indicam êstes ultimos AA..

Quanto às batidas, ZwAENEPOEL diz que elas são aproximadas duas a duas, enquanto que para Lesbre, Magliano, Ribeiro Nogueira, etc., elas são regularmente espaçadas, no passo ordinario, e grupadas aos pares em uma modalidade do passo que seria o relevado, trotado ou normando. A observação de uma modalidade do passo, feita em camara lenta, revelou que, de fáto, as batidas são aproximadas duas a duas, porém a diferença de tempo é tão pequena $(0,015$ ou $1 / 64$ de segundo), que parecem, ao ouvido, regularmente espaçadas. Devemos tambem notar, como diz Merche, citado por Goubaux e Barrier, que é impossivel encontrar-se dois animais que caminhem de identica maneira, pois sua marcha está condicionada a uma série de fatores, como sejam, a raça, a natureza do trabalho, o pêso da carga, a maneira pela qual são guiados ou montados, as condições do terreno, etc., que forçosamente fazem variar o ritmo das batidas e, consequentemente, a regularidade dos apoios. 
Relativamente à báse de apoio, Magliano, citando Schmaltz, que divide o passo em ligeiro e pesado, tendo o ligeiro báses de apoio sempre tripedais e o pesado, duas báses tripedais entre báses bipedais laterais, está em oposição à maioria, que dá para o passo as seguintes báses de sustentação: tripedal anterior esquerda, bipedal diagonal esquerda, tripedal posterior direita, bipedal lateral direita, tripedal anterior direita, bipedal diagonal direita, tripedal posterior esquerda e bipedal lateral esquerda, que foi o que tambem observámos.

Centro de gravidade - Em virtude da pluralidade dos membros em apoio, o equilíbrio é muito estavel. Os deslocamentos laterais do centro de gravidade aproximam-se aos da andadura, dos quais diferem porque o apoio em diagonal faz com que o centro de gravidade atinja suas posições extremas, de duas em duas batidas. De acôrdo com a notação da figura 37 , a projeção horizontal do centro de gravidade so-

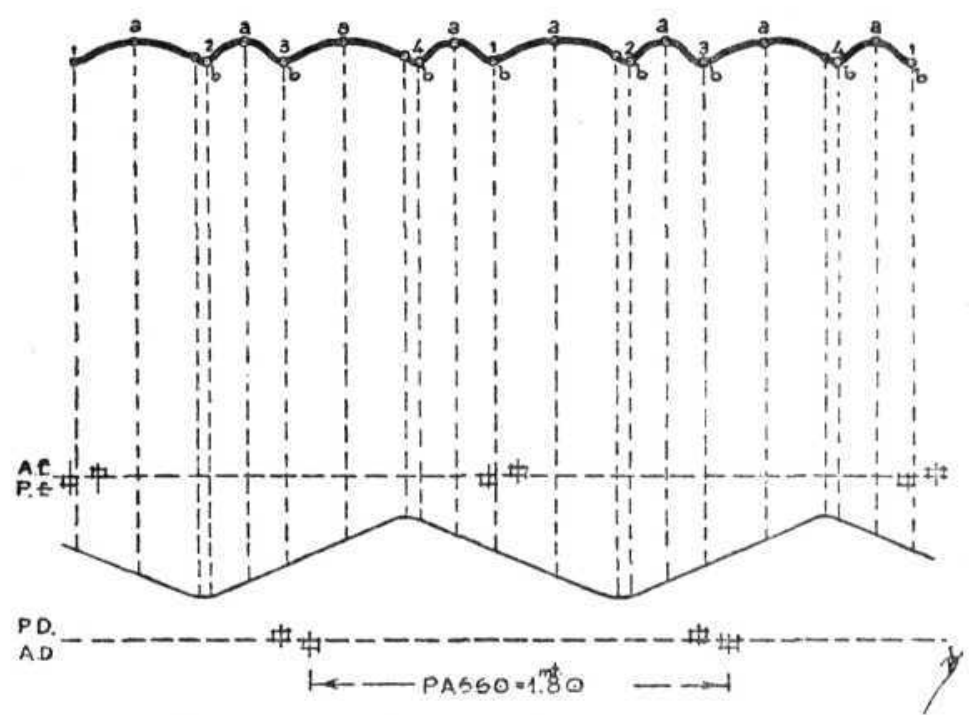

Fig. 37 - Deslocamento do centro de gravidade e pista de um animal em passo (Original)

fre um deslocamento da esquerda para a direita, aproximando-se de seu limite lateral direito, segue depois em direção oposta e avisinha-se da linha lateral esquerda. Seus pontos extremos estão localizados pouco antes das batidas dos membros posteriores, isto é, dentro do periodo de apoio bipedal lateral. Em seu deslocamento vertical, o centro de gravidade descreve curvas pouco pronunciadas, em numero de quatro para cada passo, como mostra a figura 37 . No andamento aqui estudado, cuja notação é representada na figura 38 , as curvas do deslocamento ver- 
tical não são iguais: são mais longas as que correspondem aos periodos de apoio lateral. Esta irregularidade, talvez seja observada, por se tratar de uma modalidade do passo. Os pontos mais baixos correspondem às batidas e os mais altos estão localizados, mais ou menos, no meio do periodo compreendido entre duas batidas sucessivas. No passo normal, as pégádas dos posteriores se superpõem às dos anteriores, isto é, o animal se cobre. No caso óra estudado, não se verifica a superposição das pégádas acima referida.

Modalidade - As modalidades do passo, como vimos, dizem respeito à alteração do ritmo das batidas e à maior permanencia em apoio dos bipedes laterais ou diagonais. Quando a duração dos apoios laterais é maior que a dos diagonais, a estabilidade torna-se menor e, consequentemente, maior será a velocidade. Esta modalidade, que se aproxima da andadura, poder-se-á denominar "passo andado". Quando os apoios diagonais são mais demorados, a estabilidade será maior, a velocidade menor e o passo tende para o trote, tendo, por isso, recebido o nome de passo relevado, trotado ou normando.

O andamento por nós filmado, cuja notação é representada na figura 38 , é uma modalidade que se enquadra no primeiro caso. Enquanto os bipedes laterais permaneceram em apoio $8 / 64$ de segundo, a duração dos diagonais foi de $4 / 64$ de segundo.

Pista - A pista do passo normal é simples, isto é, o animal se cobre. Será dupla no passo alongado ou encurtado. No primeiro caso o animal se ultra-cobre e, no segundo, se descobre. Como vimos a respeito das modalidades dêste andamento, o passo pode aproximar-se da andadura ou do trote e, portanto, a pista varía igualmente nêsses dois sentidos.

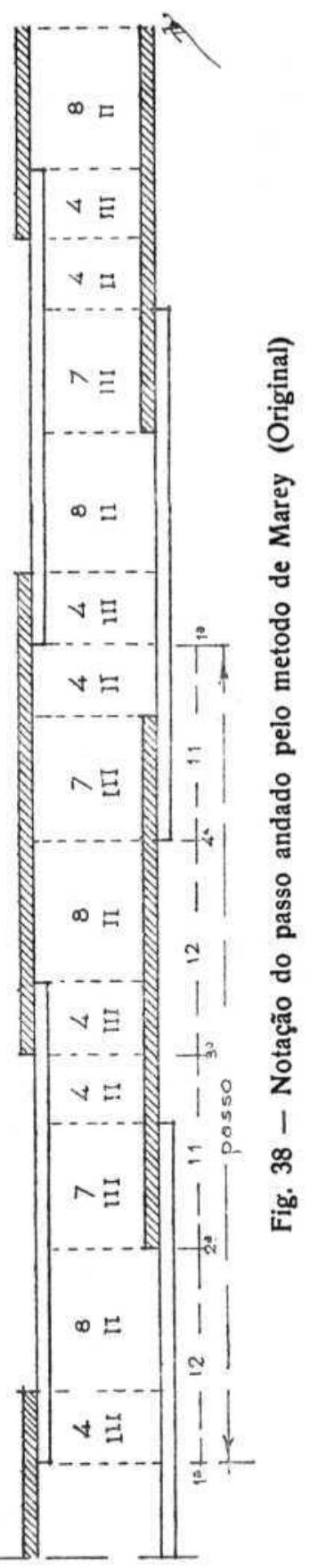

Comprimento do passo e velocidade - $\mathrm{O}$ comprimento do passo, como foi dito a proposito dos outros andamentos, é extremamente varia- 
vel. Estas variações são, não sómente individuais, como tambem observadas em um mesmo individuo. Alguns AA. dão a êste comprimento os seguintes valores: VINCENT e GoIfFON, igual ao talhe; VALLON, RaAbe e Barroil, Lenoble du TeIL, 1,80 metros para os cavalos de 1,60 metros de altura; Dunousset, comprimento do corpo medido da ponta do braço à ponta da nadega.

Quanto à velocidade, é suficiente dizer que está na dependencia direta do comprimento do passo. Em média, é de 6 a 7 quilometros por hora.

A duração dos apoios em um passo, a soma de cada um dêles e a distância percorrida em uma hora, à razão de 100 metros por minuto, são as indicadas na relação abaixo:

\begin{tabular}{l||c|c|c}
\hline & $\begin{array}{c}\text { Duracãa } \\
\text { dos apoios } \\
\text { em cada } \\
\text { passo }\end{array}$ & $\begin{array}{c}\text { Duracâa dos } \\
\text { apoios em } \\
\text { uma hora de } \\
\text { marcha }\end{array}$ & $\begin{array}{c}\text { Deslocamento do } \\
\text { corpo, sôbre cada } \\
\text { apoio, em uma } \\
\text { hora de marcha }\end{array}$ \\
\hline Trip. post. direito. . . . & $\frac{4^{\prime \prime}}{64}$ & $5^{\prime} 13^{\prime \prime}$ & $521,6 \mathrm{~ms}$. \\
Bip. lat. direito. . . . . & $\frac{8^{\prime \prime}}{64}$ & $10^{\prime} 26^{\prime \prime}$ & $1.043,3 \mathrm{~ms}$. \\
Trip. ant. direito . . . . & $\frac{7^{\prime \prime}}{64}$ & $9^{\prime} 7^{\prime \prime}$ & $911,6 \mathrm{~ms}$. \\
Bip. diag. direito . . . . & $\frac{4^{\prime \prime}}{64}$ & $5^{\prime} 13^{\prime \prime}$ & $521,6 \mathrm{~ms}$. \\
Trip. post. esquerdo. . . & $\frac{4^{\prime \prime}}{64}$ & $5^{\prime} 13^{\prime \prime}$ & $521,6 \mathrm{~ms}$. \\
Bip. lat. esquerdo. . . . & $\frac{8^{\prime \prime}}{64}$ & $10^{\prime} 26^{\prime \prime}$ & $1.043,3 \mathrm{~ms}$. \\
Trip. ant. esquerdo . . . & $\frac{7^{\prime \prime}}{64}$ & $9^{\prime} 7^{\prime \prime}$ & $911,6 \mathrm{~ms}$. \\
Bip. diag. esquerdo . . . & $\frac{4^{\prime \prime}}{64}$ & $5^{\prime} 13^{\prime \prime}$ & $521,6 \mathrm{~ms}$. \\
\hline Soma . . . . . & $\frac{46^{\prime \prime}}{64}$ & $59^{\prime} 58^{\prime \prime}$ & $5.996,2 \mathrm{~ms}$. \\
\hline
\end{tabular}

\section{Saltos}

Definição - O salto é a projeção momentanea do corpo do animal, provocada pela distensão violenta dos quatro membros ou de membros associados aos pares (LECOQ).

Modalidades - Pode ser executado em direções diversas, no decurso dos andamentos, principalmente do galope, ou sem impulso prévio. 
Quanto à direção, o salto pode ser: salto para cima, salto em altura ou salto de barreira; salto de trás para deante ou salto em extensão; salto de cima para baixo; salto para os lados, à direita ou à esquerda. Só trataremos das duas primeiras modalidades, que tomaremos como tipo para a descrição do mecanismo do salto, pois, no momento, são as unicas que nos interessam.

Quando executado no decurso do galope, o salto não é mais que um prolongamento do periodo compreendido entre os apoios do segundo e terceiro membros, isto é, dos membros diagonais associados no galope a três tempos.

Quando sem impulso prévio, o salto exige uma distensão muito energica dos membros para compensar a falta do impulso dado pelo andamento.

Uma outra modalidade é o salto de carneiro. Hayes considera-o um instinto herdado dos ancestrais dos nossos cavalos, que o executavam para livrar-se dos animais carnivoros. Para executar o salto de carneiro, o cavalo abaixa a cabeça, colocando-a entre os membros anteriores, encurva a coluna vertebral e efetua saltos pela distensão quasi simultanea dos quatro membros.

Mecanismo - Como todos os tratados classicos por nós manuseados não estivessem de acôrdo com nosso modo de vêr, parecendo mesmo, em alguns periodos, que foram decalcados uns sobre os outros, sem observações proprias, procurámos exclarecer a questão pelo exame cuidadoso de films em camara lenta, de onde tirámos as seguintes conclusões :

1) Não é certo que o salto seja um prolongamento do periodo de projeção, como dizem alguns tratadistas: na projeção do galope, o último membro a abandonar o sólo é o anterior sobre o qual o animal galópa e o primeiro a apoiar-se é o posterior oposto em diagonal; no salto normal, o último membro a deixar o terreno é o posterior do mesmo lado que o cavalo galópa, e o primeiro a apoiar-se é um anterior, geralmente o associado no galope a três tempos. Tivemos ocasião de filmar uma tentativa de salto, fracassada porque o animal, tentando transpor a barreira em periodo de projeção, foi de encontro ao obstáculo.

2) Tambem não é exato que o cavalo geralmente mude o galope, depois que passa a barreira: estando o salto compreendido entre os apoios dos membros diagonais, êle não faz alterar a ordem em que as batidas vinham sendo feitas. Se o animal galópa à direita, por exemplo, o primeiro membro a se "pôr» depois do salto não é, normalmente, o anterior direito, como dizem Goubaux e Barrier, Smith, Magliano, etc., e mostram as figuras reproduzidas pelos mesmos auto- 
res, decalcadas das fotografias instantaneas de ANschürz, de Lissa, e sim, o anterior esquerdo, que foi o primeiro a abandonar o terreno, antes do salto.

Tivemos a satisfação de ver confirmadas nossas observações na "Art equestre», de BARROIL, que posteriormente nos veiu ter às mãos. E' provavel que outros autores tenham feito observações acertadas, o que não nos foi possivel verificar em virtude da dificuldade em se obter suas óbras.

Além dos inúmeros saltos que tivemos ocasião de observar, cincoenta foram filmados. Sôbre êles nos baseámos para determinar a percentagem abaixo referida, na qual não foram computadas as observações à simples vista, embora em harmonia com as nossas previsões.

Sómente em $32 \%$ dos saltos a sucessão dos apoios foi feita de modo contrário ao por nós estabelecido, havendo mudança de galope após o obstáculo, comportando-se, portanto, conforme descreve a maioria dos AA.. Entretanto, julgamos que êsse numero poderia ainda ser mais reduzido se levassemos em consideração as seguintes observações feitas sobre alguns dêles:

1) $O$ caso da influência do cavaleiro na execução do salto, fáto êste bem evidenciado na observação do film.

2) Um cavalo que, em um salto relativamente facil, efetuou seus apoios segundo o modo que julgamos normal, contrariou-os em um salto dificil, o que nos faz supôr a possibilidade de um desequilíbrio, em consequencia de um maior esforço do animal.

3) Três animais que saltaram conforme descrevem os AA., retomaram o galope primitivo logo em seguida, parecendo-nos, portanto, tratar-se de saltos não efetuados em condições normais.

4) Um outro, que tendo mudado de galope no momento de abordar o obstáculo, positivamente não executou o salto em bôas condições de equilíbrio.

O mecanismo do salto compreende três tempos: o de preparação, o de execução e o de descensão ou apoio. No primeiro tempo do salto em altura, no decurso de um andamento, o animal aproxima mais os membros posteriores dos anteriores e eleva o pescoço, projetando a cabeça para trás. Isto determina, como vimos anteriormente, o deslocamento do centro de gravidade para trás, o que facilita a fáse seguinte.

No periodo de execução, o cavalo eleva-se sôbre o trem posterior, flexionando os membros anteriores como se fosse empinar, e distende energicamente os membros pelvicos, projetando o corpo para deante e para cima. Os membros anteriores passam o obstáculo ainda em flexão, o pescoço distendido para a frente e os membros posteriores 
distendidos ou mais geralmente flexionados, principalmente quando o obstáculo é muito alto. Nêste caso, os membros anteriores transpõem o obstáculo distendidos. Comumente observa-se que, ao transpôr a barreira, os membros pelvicos são flexionados e dirigidos para o lado.

No terceiro periodo, o pescoço se eleva e o apoio se inicia pelo membro anterior que primeiro abandonou o sólo, seguindo-se imediatamente o outro anterior. Sucessivamente êstes se deslocam para dar lugar aos posteriores, que se vêm apoiar muito proximo ou um pouco adeante do ponto por êles ocupado, na mesma ordem em que haviam abandonado o terreno. Tanto os membros toracicos como os pelvicos tocam o sólo levemente flectidos para atenuar a violencia do choque.

A figura 39 apresenta quatro fáses de um dos saltos em altura, no decurso de um galope a quatro tempos, à direita, que obtivemos pela filmagem em camara lenta.
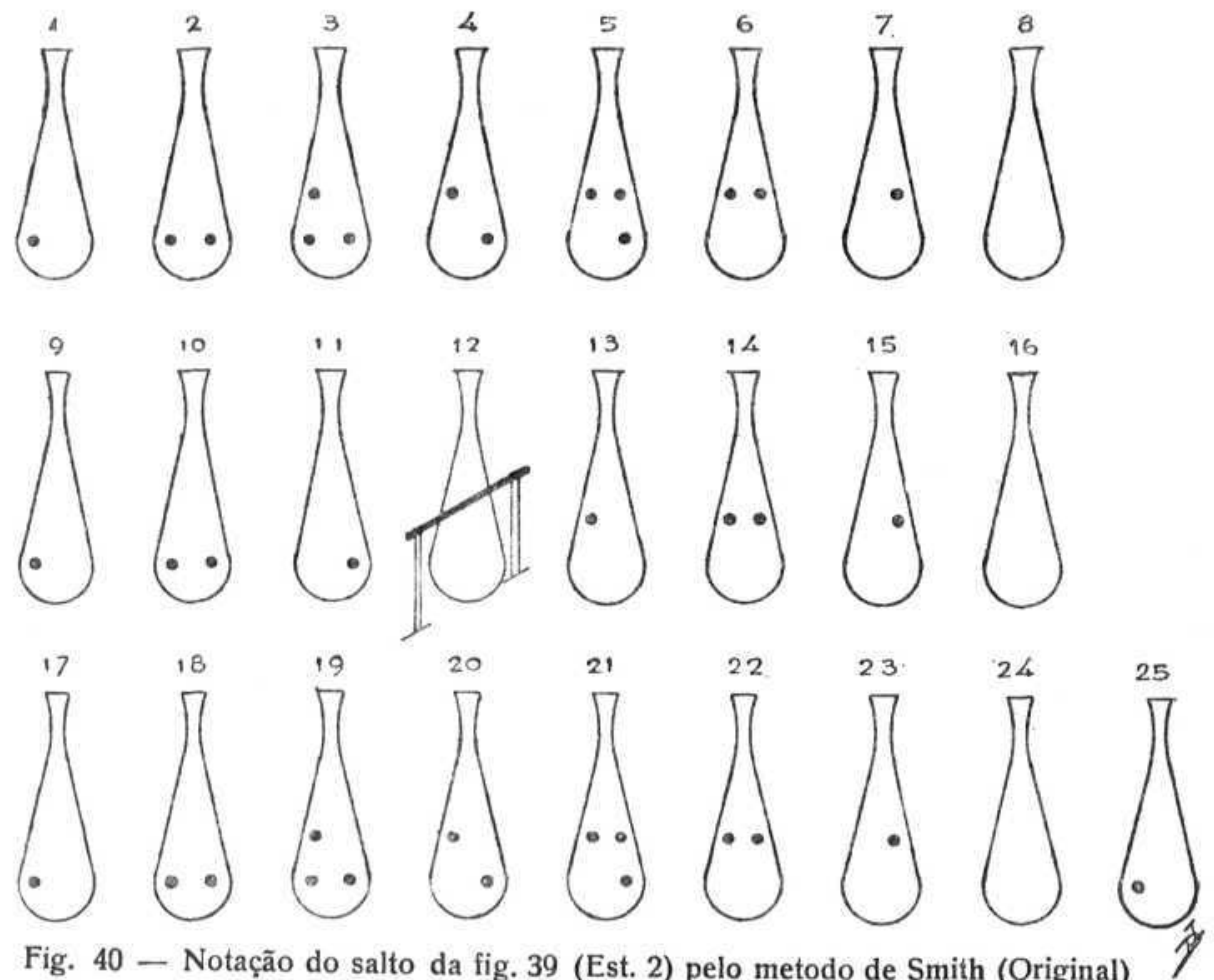

Fig. 40 - Notação do salto da fig. 39 (Est. 2) pelo metodo de Smith (Original)

Reproduzimos na figura 40, a notação detalhada do mesmo salto, pelo metodo adotado por $\mathrm{S}_{\text {MITH, }}$ que torna mais evidente as diferentes báses de apoio. As quatro fáses da figura 39 são representadas, respetivamente, em $9,11,12$ e 13 , na figura 40 . Nesta figura vemos, de 1 a 8 , as notações correspondentes ao galope, até o último periodo de 
144

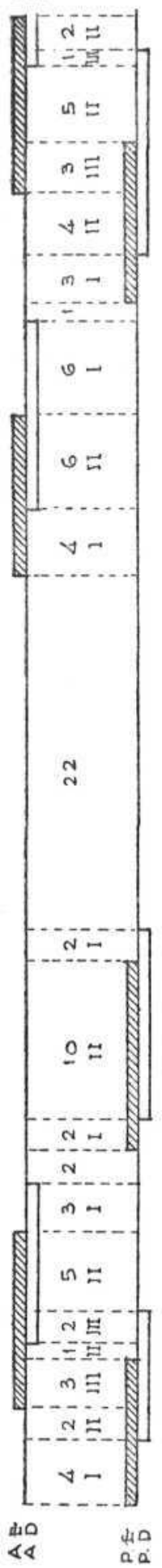

Rev. Fac. Med. Vet. S. Paulo - Vol. 1, fasc. 2, 1939

projeção antes de atingir a barreira. E' nêste momento que se inicia a fáse de preparação, pela elevação mais pronunciada do pescoço, da cabeça e de todo o trem anterior, e pelo maior adeantamento dos membros posteriores, que se vão colocar em apoio. Este se faz primeiro com o posterior esquerdo (9), mas como a instabilidade é maxima, em virtude do apoio monopedal e da posição elevada do centro de gravidade, o animal apoia, logo em seguida, o posterior direito, afim de ampliar a báse de sustentação, que passa, assim, a ser bipedal (10). Aquí começa a fáse de execução, pela distensão energica dos membros pelvicos, que se elevam do sólo, antes o esquerdo (11) e depois o direito, ao mesmo tempo que o pescoço é distendido para a frente, sendo todo o corpo projetado para cima e para deante, galgando o obstáculo. Ao aproximar-se o terceiro periodo, o pescoço é novamente dirigido para trás, afim de diminuir o pêso do trem anterior e atenuar o choque dos membros sôbre o sólo. O apoio começa com o membro anterior esquerdo (13), que foi o primeiro anterior que abandonou o terreno antes do obstáculo. A grande instabilidade de equilibrio nêste momento faz com que o apoio se torne, logo em seguida, bipedal (14), desta vez anterior, ficando o centro de gravidade situado para trás da linha de sustentação. A seguir, os membros anteriores se deslocam para dar lugar aos posteriores, sendo êste deslocamento iniciado pelo anterior esquerdo (15) e logo seguido pelo direito, determinando pequeno periodo de suspensão (16). A última fáse do salto termina pelo apoio dos membros posteriores, inicialmente o esquerdo (17) e depois o direito (18), seguindo-se o galope (19 a 25), em consequencia da inercia.

$\mathrm{Na}$ figura 41, representamos o mesmo salto, pelo metodo de MAREY, para que melhor possa ser observada a duração dos periodos de apoio e de suspensão dos diferentes membros, bem como das fáses de projeção.

Nesta notação, os numeros indicam, em 1/64 de segundo, os tempos das diferentes fáses de apoio e de suspensão. Assim, o primeiro membro aí figurado 
é o posterior esquerdo, que sustenta o pêso do corpo durante 4/64 de segundo; vem em seu auxilio o posterior direito e a báse de sustentação se torna bipedal posterior durante $2 / 64$ de segundo; apoia-se, então, o anterior esquerdo e por 3/64 de segundo a báse é tripedal anterior esquerda, e assim por deante.

A duração do primeiro apoio do membro posterior esquerdo, por exemplo, é de $9 / 64$ de segundo $(4+2$ $+3=9$ ), enquanto que a do segundo é de $12 / 64$ $(2+10=12)$; a do primeiro apoio do anterior esquerdo é igual a $11 / 64(3+1+2+5=11)$, etc.. Portanto, na execução do salto, não ha igualdade na duração dos diferentes periodos de apoio, quer de membros diversos, quer de um mesmo membro.

A notação acima mostra claramente que o último membro anterior que deixa o sólo, antes do obstáculo, é o direito, que tambem é o último anterior a apoiar-se depois do salto.

O salto em extensão é quasi sempre efetuado no decurso do trote e, principalmente, do galope, e tambem é executado em três tempos: preparação, execução e apoio.

Diz ZwaEnePoel, "Quand le saut en longueur est intercalé dans le galop, il ne constitue plus qu'un temps de cette allure, avec cette différence, que la période de suspension en l'air est prolongée et que le cheval a les quatre membres étendus, les anterieurs en avant et les posterieurs en arrière, pendant le deuxieme temps de la durée du saut», mas, como já dissémos anteriormente, o salto está situado entre os apoios dos membros diagonais associados no galope normal e não é, como refere aquele A., um tempo dêsse andamento com periodo de suspensão prolongado. O proprio A. diz que o cavalo tem os quatro membros distendidos, disposição esta que não corresponde a tempo algum do galope. Na projeção do galope, é um momento anterior o último a abandonar o sólo, e o primeiro a apoiar-se é o posterior oposto em diagonal, ao passo que, no salto, o último membro a deixar o terreno é um posterior e o primeiro a apoiar-se é, normalmente, o anterior oposto.

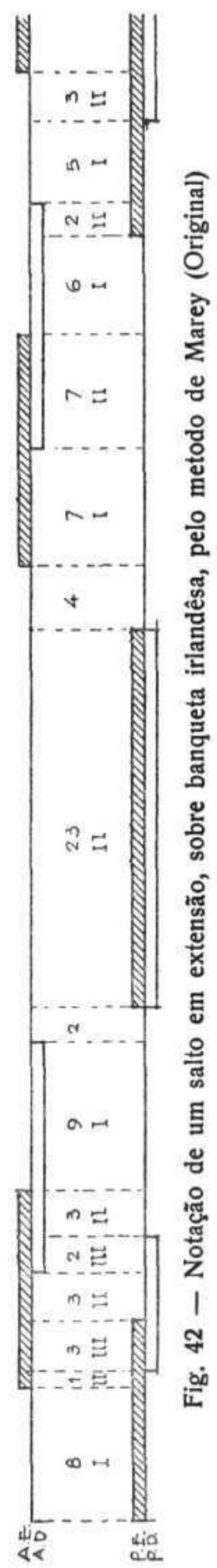




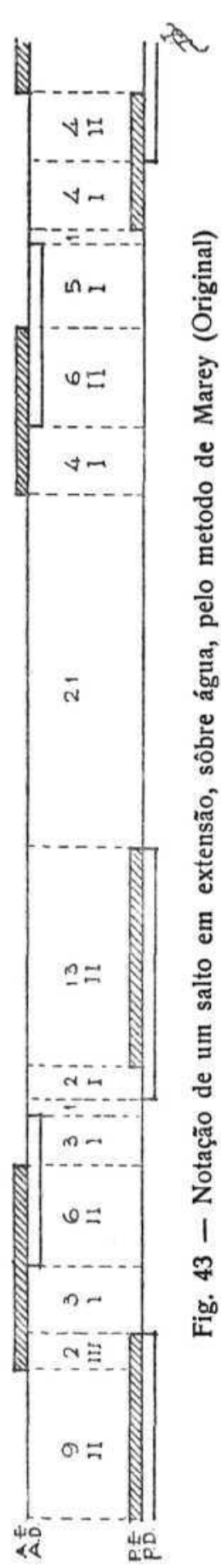

Seria mesmo para extranhar que um cavalo, com um só membro anterior em apoio, conseguisse dar ao corpo impulso suficiente para transpôr o obstáculo.

Descrevemos, linhas abaixo, um salto em extensão, sôbre banqueta irlandêsa, no decurso de um galope à direita. Nêste caso particular, como o animal é obrigado a se adaptar ao terreno muito limitado da banqueta, sofrem, naturalmente, o modo e a frequencia dos apoios, que se processam de maneira diversa, como é facilmente observado na figura 42.

Após o primeiro apoio monopedal posterior esquerdo, contrariamente ao que se dá no galope normal, observa-se o apoio do membro anterior esquerdo, tornando a báse de sustentação bipedal lateral esquerda, durante $1 / 64$ de segundo. Nota-se tambem que os membros posteriores, antes do salto e após uma fáse de suspensão quasi nula, se «põem» ao mesmo tempo e, depois de um periodo de apoio relativamente longo (23/64 de segundo), se distendem tambem simultaneamente, projetando o corpo mais para deante do que para cima. Durante a fáse de projeção do salto, executada em 4/64 de segundo, os membros anteriores e posteriores se mantêm distendidos, respetivamente para deante e para trás, sendo a cabeça e o pescoço dirigidos para a frente. O periodo de descenção é identico ao do salto em altura, isto é, os apoios se efetuam de modo analogo, porém não foi observada, no salto em apreço, a fáse de suspensão que sucede o apoio dos membros anteriores, em virtude do adeantamento do anterior direito.

A figura 43 é a notação de um salto em extensão sôbre água. Aqui não se verifica a báse de sustentação bipedal lateral esquerda; os membros posteriores se apoiam e se elevam ao mesmo tempo, no último periodo de apoio, antes da fáse de preparação; nesta, os membros referidos se «põem» um depois do outro, embora o «levantar» seja simultaneo; ha, depois do salto, o periodo de projeção que, de modo geral, precede o primeiro apoio dos membros posteriores; o galope que segue é, como geralmente acontece, do mesmo lado que o precedente ao obstáculo. 


\section{SUMMARY}

This work is composed of observations carried out upon 50 animals, filmed in slow motion, at the rate of 64 exposures a second.

For the study of locomotion, those observations were selected which featured the most typical "pace». With regard to jumping, in the majority of cases the jumps were observed of ridden animals, owing to the impossibility of so doing with them while at liberty, where the moviments would be more life-like.

Beginning by a brief historical reference to the studies which have been made on this subject, we then proceed to deal with the elementary static principles on which the equilibrium of quadrupeds is based, by comparing such equilibrium to a system of two parallel forces of the same sense applied to the horse's body.

Those forces, represented by the weights of the fore and hindquarters, have as their resultant the axis of gravity, which is the vertical projected from the centre of gravity. The situation of this point is very variable, since the moviments of the joints, the dislocation of the viscera, their variation in weight and volume, etc., cause it to vary constantly.

The determination of the axis of gravity was effected with regard to «attitudes», stationary movements, paces and leaps.

Dealing with paces as a whole, the following points are studied: periods of support and suspension; different modes of notation of paces, foot-prints and their representation; physiology of locomotion and draught, etc.; with regard to "paces» in particular, the amble, trot, canter and walk.

Of these "paces», only those conclusions are set forth, in this summary, which differ from the usual descriptions in the text-books.

In the study of each kind of locomotion, the definition, notation, dislocation, of the centre of gravity, gaits, foot-prints, length of stride, speed and any defects, when such exist.

In order better to observe the dislocation of the centre of gravity, foot-prints, and vertical and horizontal projections of the said centre are grouped together in one and the same plate (Figs. 16, 21, 28, 37). This diagram, although merely outlined, shows the localisation of the centre of gravity during any period of the "pace» under consideration. In order to obtain the vertical projection, employing the artifice of considering the centre of gravity to be fixed in the body of the animal and of considering it to be a point situaded in the girths, the following method was observed: during the filming of an ambling animal, for instance, the height of the girths and the distance A of its horizontal projection to the middle of the hoof of the left fore-leg, 
were taken at the moment when the left fore-leg struck the ground (Fig. 14-1). These two coordenates determined the first point of the curve. In the following figures of the left lateral support, the different heights of the girths and the respective distances of their horizontal projection to the same fore-leg were noted. These data supplied other points of the graph, including the highest and lowest points of displacement. When the movement of the right hind-leg took place (Fig. 14-2), there were further registered the height of the girths and the distance $\mathrm{B}$ of its horizontal projection to the left fore-leg.

A minus $\mathrm{B}$ is the distance moved by the centre, between the two successive impacts. Next, taking the right hind-leg as a point of reference, the same method was continued, until the moment of the impact of the right fore-leg (Fig. 14-5) and so on, until a stride was completed. The different points so obtained determined the vertical projection of displacement, and, at the same time, permitted the foot-prints of the animal to be drawn.

The diagram of the horizontal projection of the displacement was drawn theoretecally, with the help of the data collected as above.

An identical process was adopted in the case of the other paces, except that, in the jumps, a fixed point of reference on the ground was taken to determine the displacement of the centre of gravity during the periods of suspension.

The a mble. - Although many animals, while ambling, at first sight give the impression that they are using the typical pace described by different authors, it can be verified, by observing the film, that it is a question of "shades» of the amble it even appearing probable that the typical amble is a theoretical pace, around which several "shades» vary. Therefore, the "pace» that served as a basis for the determination of the centre of gravity is a variety of «interrupted amble», to which not a single one of the authors consulted refers. From the analysis of its notation (Fig. 19) the following conclusions result: a) there is an evidente predominance of the lateral supports; b) the periods of support of the hind-legs are longer than those of the fore-legs; c) the hind-legs touch the ground and leave it before the fore-leg of the same side; d) there is a short period of mono-pedal posterior support; $e)$ between the two periods of lateral support, there is one of tri-pedal support, one of diagonal bi-depal and one mono-pedal.

With respect to the displacement of the centre of gravity, it is seen by figure 16, that: a) the centre of gravity, in its vertical displacement, describes two smooth curves - two for each stride; b) those curves do not show any angles of inflection at their lowest point, as is 
generally accepted; c) both the highest and the lowest point are verified during the lateral bi-pedal supports; d) the curves described during these periods, are longer than those verified during the tri-pedal, diagonal bi-pedal and uni-pedal supports, which is in accordance with the duration of those supports; $e$ ) in the projection of the horizontal displacement, the nearest point of the base of lateral bi-pedal support corresponds to the instant of the impact of the fore-leg on the same side.

The trot. - The determination of the displacement of the centre of gravity, in the trot, was made in regard to the ordinary pace, and figure 21, so obtained, shows that the vertical displacement describes curves, two for each stride, the greatest height of which corresponds to the periods of suspension, while the smallest one approximately corresponds to the middle of the periods of support.

The canter. - The centre of gravity, in its vertical displacement (Fig. 28), describes curves similar to those of the trot, these being however, larger and smoother, since in the trot there are two periods of suspension to each stride and, so, two curves, where as in the canter there is only one, and therefore only one curve. The highest point of this displacement is to be found near the end of the period of projection; the lowest one, within the period of support of the associated bipedal diagonal.

In change of canter, the transition consists of a disjointed cantering stride, there not existing, however, any association of the lateral bi-pedals; it is precisely a stride of a rotatory canter, which, according to MUYBRIDGE, does not exist as regards the horse.

The walk. - In the walk, the curves of vertical displacement of the centre of gravity (Fig. 37) are similar to those of the amble. The highest points are situaded, approximately, at the middle of the periods of support and the lowest ones correspond to the moment of the impact. The curves corresponding to the periods of lateral support are longer, which perhaps may be explained by the fact that we are dealing with a varriety of gait, in which there is a predominance of the lateral supports. This variety may be termed the "walking-pace».

With regard to the $j u m p s$, the following were studied; definition, forms and mechanism. The study of the mechanism of the jumps was carried out over 50 leaps (hig and long jumps) filmed in slow motion, of which 34 were executed under conditions considered normal in this work. From figures 39 to 43, which reproduce some of them, we verify: a) the crossing of obstacle is effected between the instants of support of the diagonally associated members in the canter; b) the 
later hind-leg to leave the ground is also the later in coming down on the other side of the obstacle, that is, in the right-hand-side canter, the first leg to touch the ground will be the left fore-foot and vice-versa; c) there is no change of gallop.

The remaining 16 leaps were effected as the treatises describe, that is, by changing gallop on jumping the obstacle. In this case, the latest fore-leg to leave the ground is the first to touch the ground on coming down.

These 16 cases, however, might be cut down, if one took into consideration the special circumstances under which some of them were effected, such as; the rider's influence on the execution of the leap a difficult obstacle to be jumped - changing the jeet very close to the obstacle, and so on.

\section{BIBLIOGRAFIA}

Barroll, E. - 1887 - Art Equestre. I parte. Traité de equitation de haute ecole. Paris. Rotschild.

Battelli, A. \& Cardani, P. - s. d. - Trattato di Fisica Experimentale. Vol. I. Milano. Francesco Vallardi.

Chaves de Lemos, A. A. - 1903 - O Cavalo. Porto. De Lello \& Irmão.

ChIARI, E. - 1897 - Trattato di Ippologia. Vol. I. Torino. Unione Tipografico editrice Torinese.

Ellenberger, W. \& Baum, H. - 1932 - Handbuch der vergleichenden Anatomie der Haustiere. Berlim. Verlag von Julius Springer.

Fontaine \& Huguier - 1924 - Nouveau Dictionnaire Vétérinaire. Vol. I e II. Paris. J. B. Baillière et Fils.

Goubaux, A. \& Barrier, G. - 1890 - L'Extérieur du cheval. Paris, Asselin et Cie.

HAYES, M. H. - 1930 - Points of the horse - A treatise on the conformation movements, breeds and evolution of the horse. Fifth edition. London. Hurst \& Blackett Limited.

Laulanié, F. - 1905 - Eléments de Physiologie. Deuxième édition. Paris. Asselin et Houzeau.

Lesbre, F. X. - 1922 - Anatomie comparée des Animaux Domestiques. Vol. I. Paris. Baillière et Fils.

Lesbre, F. X. - 1930 - Precis d'Extérieur du cheval et des principaux mammifères domestiques. 3 ème. ed. Paris. Vigot Frères.

Magliano, A. - 1929 - Ezoognosia generale. Torino. Unione Tipografico - editrice Torinese.

Magne De La Crotx, P. - 1932 - Evolucion de la locomocion terrestre en los vertebrados. Rev. Med. Vet. XV a XIX (2 a 6). Marzo a Diciembre. Buenos Aires.

Marchi, E. - 1901 - Ezoognosia. Vol. I. Milano. Francesco Vallardi.

MarcQ, J. \& Lahaye, J. - 1934 - Extérieur du cheval. Gembloux. Jules Duculot.

Miranda do Vale, J. - 1934 - Exterior do cavalo. 2.a parte. Lisbôa. Empresa Nacional de Publicidade. 
Nogueira, O. R. - 1920 - Exterior dos Grandes Animais Domesticos. S. Paulo. Soc. Edit. Olegario Ribeiro.

Preziuso, L. - 1925 - L'arto pelvico in appoggio nella stazione libera degli equini. Estratto dal Nuovo Ercolani, n.o 13, 14, 15-16. Torino Tipografia Giulio del Signore.

Rocha LAgôA, T. - 1928 - Dos andamentos e da anatomia morfologica do membro pelvico do cavalo Campolina. Tése. Rio de Janeiro.

Sмгтн, F. - 1921 - A manual of veterinary physiology. Fifth edition. London. Baillière, Tindall \& Co.

Zimmerl, U. - 1929 - Trattato di Anatomia Veterinaria. Vol. I. Milano. Francesco Vallardi.

Zwaenepoel, H. - 1926 - Précis du cours d'extérieur du cheval. Bruxelles. G. Bothy. 


\section{EXPLICAÇÃO DAS ESTAMPAS}

Est. $1\left\{\begin{array}{c}\text { Fig. } 11 \text { - Atitude de um animal ao iniciar a tração (J. MARCQ - J. LAHAYE). } \\ \text { Fig. } 19 \text { - Instantaneo da andadura de uma egua Mangalarga e notação do } \\ \text { andamento. }\end{array}\right.$ A - processo de Marey

B - processo de Smith (Original)

Est. 2 - Fig. 39 - Instantaneo de um salto em altura.
A - apoio monopedal posterior esquerdo
B - apoio monopedal posterior direito
C - projeção
D - apoio monopedal anterior esquerdo (Original). 
A. Chieffie L.Homem de Mello, Desl. centro grav. cavalo Rev. Fac. Med. Vet. S. Paulo, Vol. 1, fasc. 2
Estampa 1

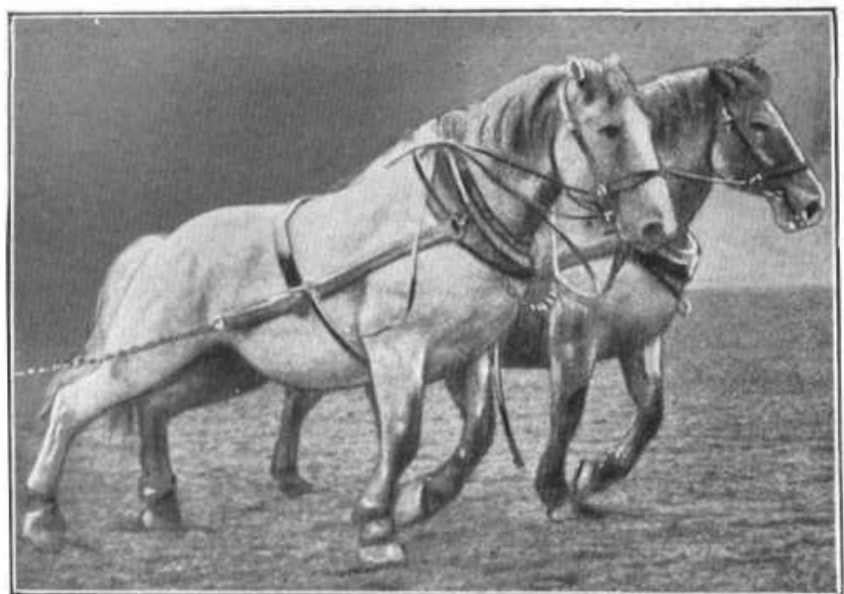

Fig. 11
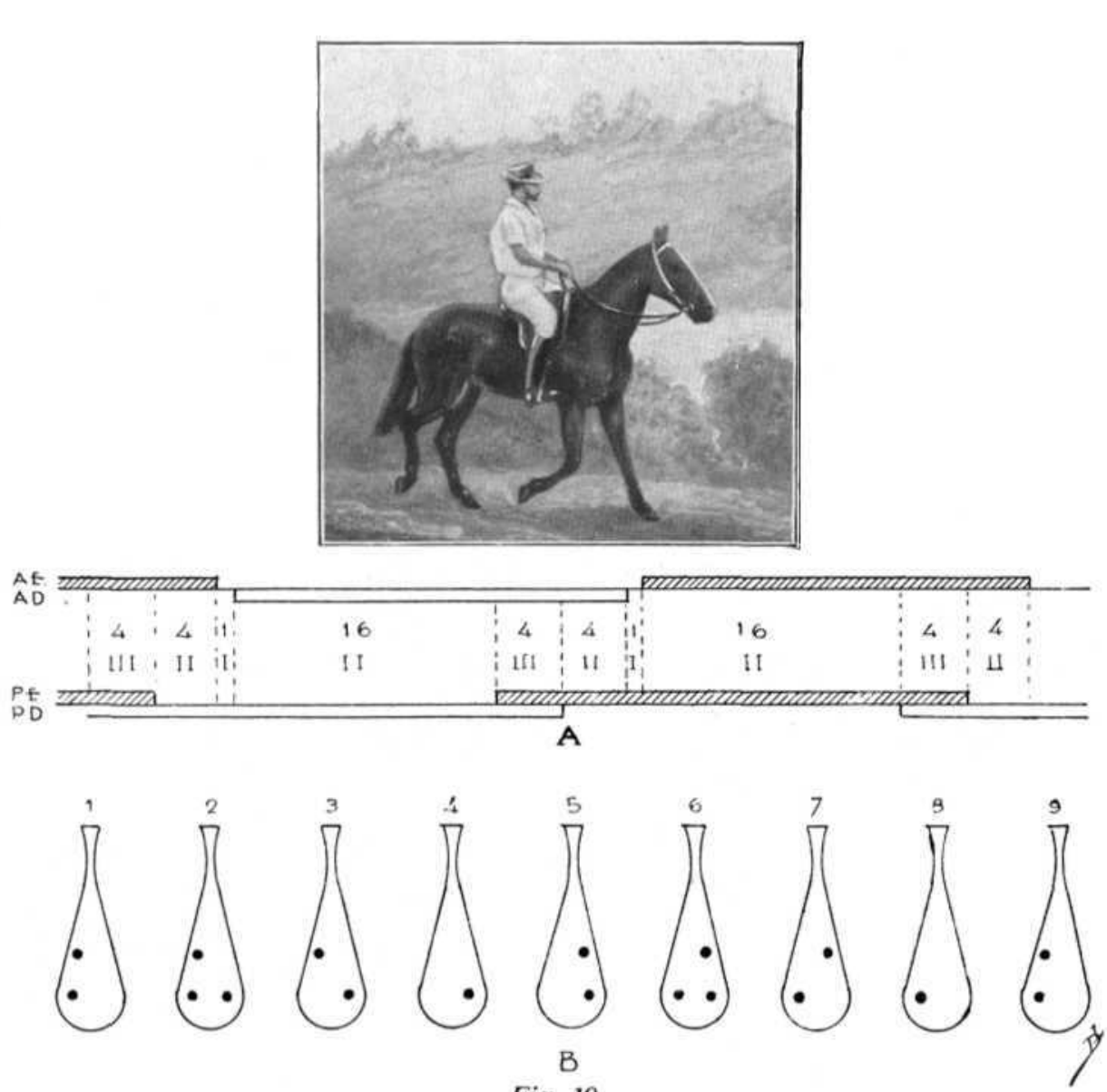

Fig. 19 
A. Chieffie L. Homem de Mello, Desl. centro grav. cavalo Rev. Fac. Med. Vet. S. Panlo, Vol. 1, fasc. 2
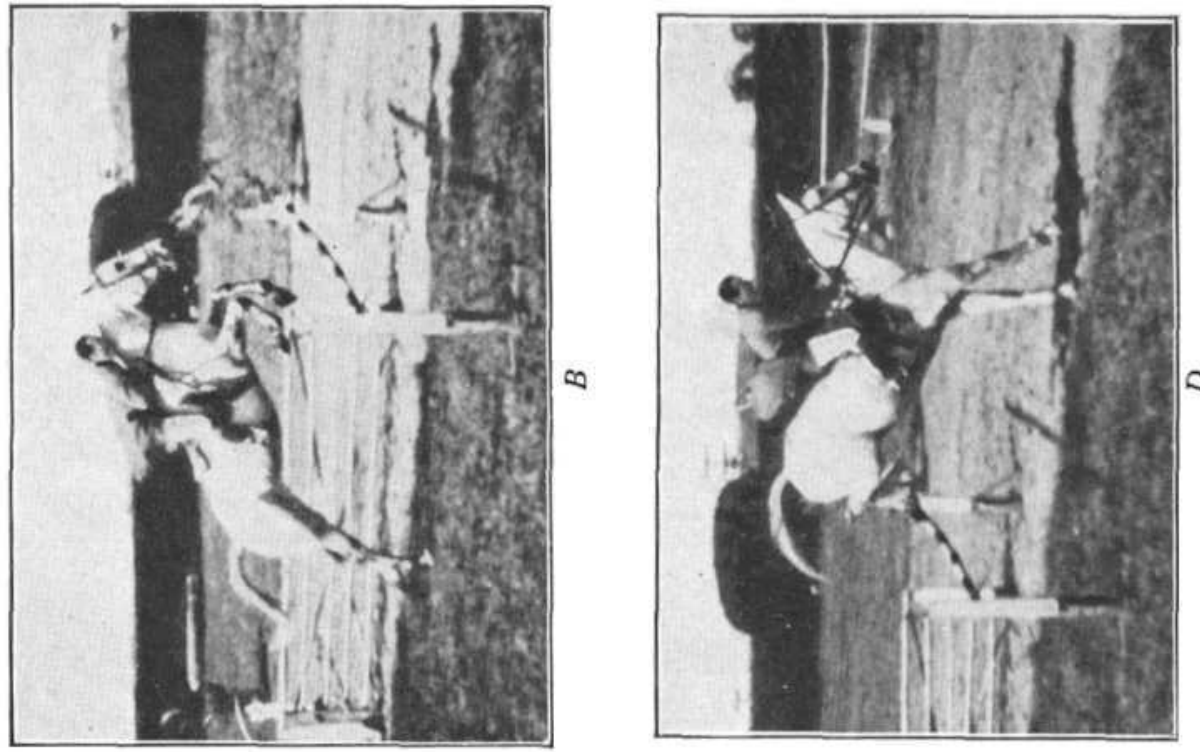

Q

ले
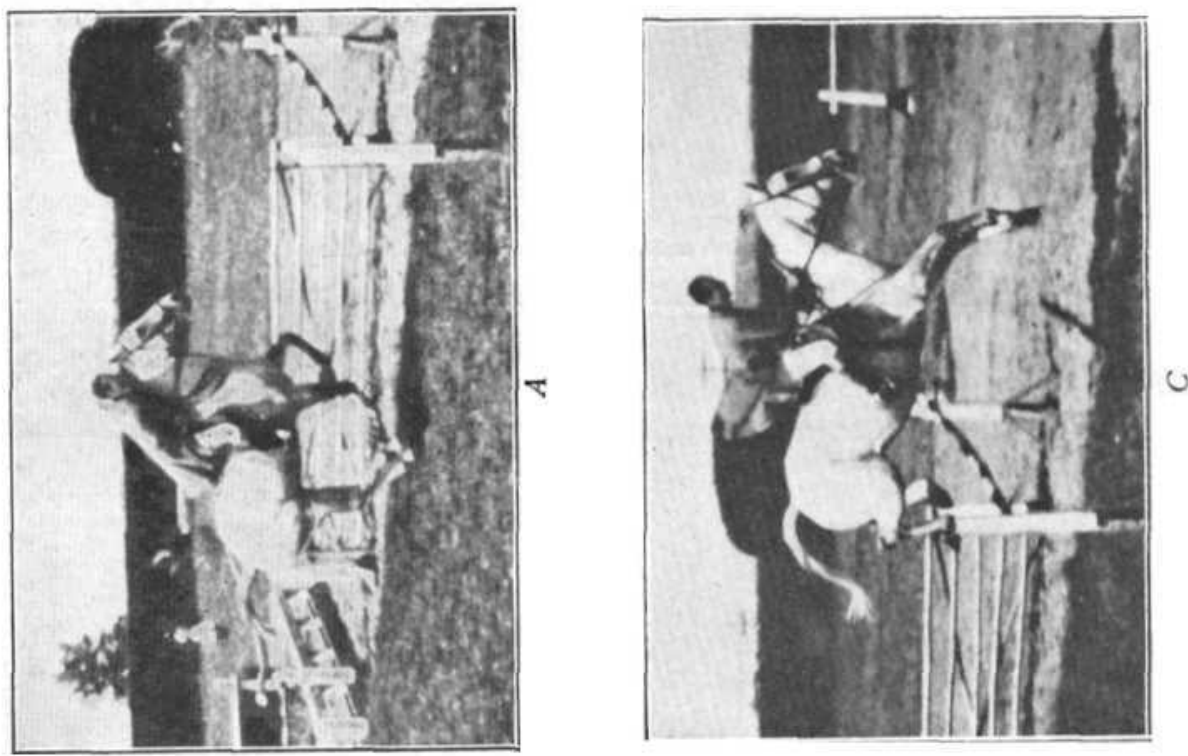